\title{
Substitution of Wheat Flour by Local Cereals and Pulses Flour "An approach to overcome wheat gap in Egypt" 4. Bread Sensory Panel and Stalling Test
}

\author{
M. Abd El-Sattar Ahmed ${ }^{1 *}$, Zeinab R. Atia ${ }^{2}$ and M.M El-Genbeihy ${ }^{3}$ \\ 1 Professor, Crop Science Dept., Fac. Agric. (El-Shatby), Alexandria University \\ (Mohamed.A@alexu.edu.eg) \\ 2 Lecturer, Crop Science Dept., Fac.Agric. (El-Shatby), Alexandria University. \\ (Zinab.atia@alexu.edu.eg). \\ 3 Professor, Crop Science Dept., Fac. Agric. (El-Shatby), Alexandria University . \\ * Corresponding author.
}

\begin{abstract}
The main objective of the recent study was to assess the possibility of substituting local cereals flours represented by rice, sorghum and naked barley to wheat flour. Three separate experiments were carried out each included one of the local bread wheat varieties. Raise in rice flour substitution level to $30 \%$ caused an increase in scored crust smoothness reached the level of significance, only with Gimmeza11 wheat flour. Increasing the level of sorghum or barley flour substitution from 10 to $20 \%$ of Giza171 or Gimmeza11 wheat flours resulted in lower score of crust smoothness. That reduction in crust smoothness score reached the level of significance only with Gimmeza11 wheat flour. Also, raising the level of barley flour substitution to $30 \%$ of Misr2 wheat flour gave a significant reduction in crust smoothness. In Giza171 wheat flours, increasing sorghum flour substitution level from 10 to 20 or from 20 to $30 \%$ were proportional to lack of symmetry in loaves shape, although, that deduction was only significant with increasing substitution level from 20 to $30 \%$. Gimmeza11 wheat flour respond oppositely to Misr2 wheat flour, since, loaves shape symmetry reduced with increasing sorghum flour replacement from 10 to $20 \%$, but with increasing the level of substitution to $30 \%$, symmetry of loaves improved. Misr2 wheat flour blend with $10 \%$ rice flour had darker loaves than blends with $20 \%$ rice flour. Meanwhile, opposite trend (lighter color or bale) were noticed with blends of Giza171 and Gimmeza11 cultivars with significant effect. Meanwhile, blends of Giza171 or Gimmeza11 wheat flours with $20 \%$ rice flour gave darker loaves than blends with $30 \%$ rice flour.Misr2 flour blends with $10 \%$ sorghum flour produced darker crust relative to blends with $20 \%$ sorghum flour. Meanwhile, the opposite was true with Giza171 and Gimmeza11 blends. Rice flour substitution gave bale loaves crust color relative to sorghum flour in all studied three wheat cultivars. Also, loaves of rice flour blends had lighter crust color than those of blends with barley flour. Blends with rice flour surpassed those with sorghum and barley flours in loaves ability to roll and fold, when substituted Misr2 or Giza171 wheat cultivars. In the meantime, Gimmeza11 blends with sorghum or barley flours surpassed those with rice flour in ability to roll and fold. Loaves of blends contained soybean flour produced loaves of higher ability to roll and fold relative to those contained fenugreek flour. That was assured for all wheat cultivars. Giza 171 and Gimmeza11 wheat flours with $10 \%$ rice flour replacement, showed better quality of separation than blends with $20 \%$ rice flour. Meanwhile, raising the level of rice flour in blends to 30\% decreased the score of separation quality. Giza 171 and Gimmeza11 wheat blends with $10 \%$ sorghum flour significantly expressed better quality of separation than blends with $20 \%$ sorghum flour. While, increasing the level of sorghum flour to $30 \%$, substantially improved quality of separation than blend with $20 \%$ sorghum. Blends of Misr2 or Gimmeza11 cultivars with sorghum flour gave better evenness of layers in comparison with blends with rice flour. Also, blends of the formally stated wheat cultivars with barley flour, expressed better evenness of layers than the corresponding blends with rice flour. Giza171 wheat flour blends with rice flour, expressed better evenness of layers in comparison with blends included sorghum flour. In the meantime, blends with rice flour gave better evenness of layers in comparison of those included barley flour. Raising the level of rice flour substitution to 20 or $30 \%$ of wheat flour maintained bread fresh ability (395.8 and $433.1 \mathrm{~g} \mathrm{~cm}^{-2}$ for blends of 20 and $30 \%$ rice flour, respectively), inclusion of fenugreek flour in blends of wheat + rice flour reduced bread fresh ability through raising the level of hardness $\left(927.6,765.3\right.$ and $753.7 \mathrm{~g} . \mathrm{cm}^{-2}$ for blends with fenugreek flour at $10 \%, 20 \%$ and $30 \%$ rice flour substitution levels, respectively).Soybean flour inclusion to blends produced bread of intermediate hardness values between blends with fenugreek flour and full wheat flour (605.5, 633.1 and $771.5 \mathrm{~g} . \mathrm{cm}-2$ for blends with soybean flour at 10, 20 and 30\% rice flour substitution).
\end{abstract}

Key words; Substitution, Wheat Flour, Cereals, Pulses, Bread quality, Sensory Panel, Stalling Test.

\section{INTRODUCTION}

Wheat cultivars within species differed in grain composition and quality of processing. The later gained more importance in grain trade which reflect grains attributes associated with processing quality. Grain protein content varies between 8 and 17 percent, depending on genetic make-up and production factors. The insoluble protein form in wheat flour when come to contact with water, shows the viscoelastic mass of gluten, which represents about 78 to 85 percent of total wheat endosperm protein. This type of protein is complex composed of polymeric and monomeric proteins known as glutenin and gliadin. Glutenin confer elasticity, while, gliadins confer mainly viscous 
flow and extensibility. This is how gluten is responsible for viscoelastic properties of wheatflour dough. It is also the main character dictating the proper use of wheat variety. Gluten viscoelasticity for end -use purposes is commonly known as flour or dough strength. (Qarooni et al., 1987). Roughly, wheat flour contains the same amounts of glutenin and gliadin the unbalance of glutenin/gliadin ratio may change the viscoelastic properties. The fraction of gluten is, however, the major protein factor responsible for variation in dough strength among wheat varieties (Rozylo and Laskowski, 2011).

In Egypt, bread is traditionally produced from wheat 'triticum aestivum' flour. Due to high demand, about $50 \%$ of needed wheat is imported. The inability to sustain the national wheat imports for making wheat-based foods, makes is imperative that some substitutes for wheat must be incorporated in the bread preparation. Using an alternate flour in bread making was introduced many years ago

Alternative non wheat cereals that has capacity to substitute wheat in bread flour in Egypt, includes barley, maize, rice and sorghum .Maize 'Zea mays' is rich in energy and good quality protein but, the pericarp fraction, which contain 77.7-84.6\% dietary fiber (Gupta and Singh,1981), adheres tightly to the outer surface of aleuronelayer, so that, cannot be removed easily and become responsible for decreasing digestibility and smoothness of dough. Finally produce Fast staled bread. Rice 'Oryza sativa' is the second cereal crop in Egypt after wheat. Regarding the total produced quantity (9.46 and 5.72million tons for wheat and rice, respectively (Yearbook of Agricultural Statistics, 2016). A large quantity of broken rice grains results during the processing of rice which amount to 500.000 tons annually. The nutritional contribution of rice flour goes to its content of amylase protein and low molecular weight sugar. Naked barley 'Hordeum Vulgare' is proposed as an alternative to wheat cultivation in marginal land of Egypt and under limited water allowances, Besides, the required processing and milling techniques are similar for wheat and barley. The total produced quantity of barley grains reach 130,000 ton most of it is covered grains. Sorghum 'sorghum bicolor' is anobligative cereal to upper Egypt, where, climatic condition enables yield proliferation and people consume sorghum bread. Total of one million ton of sorghum grains is produced annually (Yearbook of Agriculture Statistics, 2016).

Lópezet al. (2004), found that rice flour bread presented the best parameters, being preferred by the sensory evaluation panel, followed by corn starch bread and cassava starch bread. Breads prepared with rice flour resulted in a softer product, presenting a better consistency with small alveoli homogeneously distributed. As far as crumb texture was concerned, corn starch bread presented larger alveoli. Also, production parameters were established based on these results and a mixture of flours, composed by $45 \%$ rice flour, $35 \%$ corn starch and $20 \%$ cassava starch presented good results originating bread with crumb formed by uniform and well distributed cells, and pleasant flavor and appearance. Islam et al. (2011), reached that, bread having $8 \%$ maize and $8 \%$ brown rice flour had the most acceptable flavor, texture, color and overall acceptability when compared with other bread with maize and brown rice flour. Rai et al. (2012), determined bread making quality and sensory qualities of breads produced from varying substitutions of rice flour and maize meal with wheat flour. They indicated that, the sensory evaluation revealed that $25 \%$ replacement of wheat flour was found to be more acceptable than control sample. Khoshgozaran-Abras et al. (2014), indicated that, it was feasible to incorporate brown rice (BR) flour for baking flat bread; However, the threshold of BR flour addition should be $\leq 5 \%$. This is simply because, dough made from blend flour fortified with $5 \%$ BR flour, due to rheological evaluation, was strong and baked flat bread was highly ranked acceptable by panelists and remained fresher in comparison with other treatments by the end of storage.

Sibanda et al. (2015) studied the effect of partial substitution of wheat flour with white grain sorghum flour on bread making quality of the composites. Composite flours containing $10 \%$, $20 \%$ and $30 \%$ sorghum were analyzed There was a significant decrease in bread volume with sorghum replacement of higher than $20 \%$. The sensory analysis of the baked product indicated that, there was no significant difference in the taste, flavor and texture of the composite bread. The incorporation of sorghum at $10 \%$ produces bread of similar quality to wheat flour. Although increasing wheat replacement negatively affects the physicochemical and rheological properties, the sensory quality of the bread remains acceptable.

Niffenegger (1964) resulted showed that, the starch and proteins of barley and wheat flour behave differently. The starch of barley flour has less thickening capacity and less water absorption than wheat. The protein has less gluten-like strength. Baked products which are dependent on glutenlike strength are made less successfully from barley flour than from wheat flour. Appearance and flavor are usually affected by the addition of barley flour. Methods using little manipulation are more successful with barley than those which require extensive mixing. Sollars and Rubenthaler (1971), reported the role of starch in three soft wheat flour tests studied using reconstituted flours. They showed that, reconstituted flour with barley starch proved very good for cakes and cookies ad had viscosities close to this of flour with wheat starch. These results indicate that starch must have certain 
physical and chemical properties for satisfactory performance. Dhingar and Jood (2002), studied the physico-chemical and nutritional properties of cereal pulse blends for bread making. Supplementation of soy (full fat and defatted) and barley flours to wheat flour at 5, 10, 15 and $20 \%$ levels were studied. They found that, the gluten content and sedimentation value of flour blends decreased, and water absorption capacity increased with increase in the level of soybean and barley flour separately and in combinations to bread flour. All the blends at $20 \%$ levels were found nutritionally superior, but breads prepared from them found organoleptically unacceptable. However, addition of $15 \%$ barley flour, $10 \%$ full fat soy flour, $10 \%$ defatted soy flour, $15 \%$ full fat soy flour+ barley flour and $15 \%$ defatted soy flour+ barley flour to wheat flour not only increased the total protein, glutelin (protein fraction), total lysine, dietary fiber and $\beta$ glucan contents of cereal-pulse blends for bread making, but, could also produce a product of acceptable quality. Dhingra and Jood (2004), studied the effect of supplementation on the functional, baking and organoleptic characteristics of bread. they indicated that bread volume decreased with increasing amount of non-wheat flour substitution. The crumb color changed from creamish white to dull brown and a gradual hardening of crumb texture was observed as the addition of soybean (full-fat and defatted) and barley flours increased. It may be concluded that the substitution of wheat flour with soybean and barley flour up to an amount equivalent to $10 \%$ of full-fat and defatted soyflour, $15 \%$ for barley flour, full-fat soy + barley flour and defatted soy + barley flour produced acceptable bread loaves with good organoleptic characteristics.Ereifej et al. (2006), suggested that, barley flour can be used to replace $30 \%$ to $45 \%$ of wheat flour in Balady bread loaves without adversely affecting the consumer acceptability of the bread. However, when increasing barley flour content beyond these limits, the resulting bread loaves are found to be harder, darker in color, and nonuniformly shaped; therefore, less acceptable bread. Sullivan et al. (2010), produced doughs and breads using pearled barley flour (PBF) in different ratios $(30,50,70$ and $100 \%)$ to wheat flour. A $100 \%$ wheat flour formulation was used as a control. They found that, a low protein content usually signifies a reduced baking quality, so this result would suggest that, the inclusion of barley flour into the bread formulation would decrease the quality of the resulting breads. Increasing the pearled barley flour concentration significantly decreased the volume of the breads. Also, Hardness was found to increase significantly with an increased inclusion of barley flour and was also found to significantly increase the rate of staling of the breads, as was predicted from the starch retrogradation results of the flours. The fiber contents of the breads increased significantly with the increase in pearled barley flour to the formulation. Beta-glucan levels were found to significantly increase with the increase in pearled barley flour in the flour formulation. Taste panel results indicated that, the addition of barley flour to a wheat flour formulation does not have a significant effect on bread acceptability up to $50 \%$ barley flour addition. The results would indicate that, there is potential for a bread product containing up to $50 \%$ barley flour. Lin et al. (2012) used steamed bread incorporated with barley flour at 10 , 20 and 30\% substitution levels. They found that, increased levels of barley flour caused significant decreases in the specific volume, brightness and whiteness index of steamed bread, as well as increases in hardness and chewiness. Hussein et al. (2013), focused on substituting a part of wheat flour (WF) with whole meal barley (WBF), gelatinized corn flour (GCF) and both of them in balady bread. Sensory properties of the separation layers and roundness were not affected significantly. But a significant difference was observed in taste, crust color and odor at replacement level of $30 \%$. Generally, WF supplemented with WBF: GCF $(30: 15 \%)$ did not affected technological quality of balady bread and improved its nutritive values.Also, improved the nutritional, healthy values and quality of balady bread by replacing wheat flour (WF) with gelatinized corn flour (GCF) and/ or whole meal barley (WBF), with the possibility of completing shortages of wheat raw material. The chemical, rheological, sensory and stalling properties of the obtained balady bread were evaluated, and they concluded that, wheat flour could be replaced with whole barely flour and gelatinized corn flour at the level of $30: 15 \%$ without drastic effect on the technological quality and sensory properties of bread. Maiya et al. (2013), demonstrates that, parotta enriched with dietary fiber and $\beta$-glucan can be prepared by partially substituting wheat flour with barley flour (BF). Sensory analysis showed that, the use of barely flour above $30 \%$ brought about adverse effect on the quality of parotta. They found that, during 48 hours of storage, parottas with $30 \%$ barley flour remained softer than control parotta. Reddy et al. (2013), evaluated the milling quality characteristics of different cereals and organoleptic evaluation of traditional food products. They found that, barley comes under cereal grains and is staple food in most countries of the Middle East. It is having almost equal importance to wheat. However, it is less palatable than wheat. Flour made from barley can be used as substitute for wheat flour. Further research is needed to improve the palatability of barley and to formulate more barley recipes. Mariotti et al. (2014), showed that, the barley sourdoughs investigated could be used to obtain barley bread with enhanced nutritional value. Furthermore, despite the lower specific volume and denser crumb of barley breads with respect to wheat 
bread, no significant differences were seen in the degree of liking among the three breads after baking and during shelf-life, thus confirming the possibility for successful exploitation of barley flour in the baking industry. Tulse et al. (2014), carried out a study on the co-milled straight run flours obtained by varying proportions of wheat, barley and green gram. Mixing ratios were (90:5:5), (80:10:10) and (70:15:15). Flours were used in a cookie baking experiments. as the amount of GG and BR increased in blend, water absorption increased (56.6-58.4\%) and dough stability and extensibility values decreased (104-92 mm). Hardness of cookie doughs ad spread ratio (7.70-6.00) of cookies decreased and breaking strength values increased from 2900 to 3700 . $g$ in cookies made using co-milled blends.

Sharma et al. (1999), studied the effect of replacement of wheat flour with cowpea flour on sensory characteristics of some of the baked products. They indicated that, loaf volume and overall acceptability scores of breads were reduced significantly beyond $150 \mathrm{~g} \mathrm{~kg} .1$ incorporation of cowpea flour. Abdel-Kader (2000), evaluated the physical, rheological and baking properties of decorticated cracked broad beans-wheat composite flours and to determine the acceptability of the resulting bread using organoleptic tests. He found cracked broad beans flour (DCBF) was used to replace $5 \%, 10 \%$, $15 \%$ and $20 \%$ of the wheat flour (WF) in bread. The sensory properties of 'Balady' bread showed that, at the two levels of $5 \%$ and $10 \%$ DCBFsubstitution, the 'Balady' loaves did not show any significant differences $(\mathrm{P} \geq 0.05)$. It was concluded that, the replacement of bread flour (WF) with up to $10 \%$ decorticated cracked broad beans flour produced acceptable Egyptian 'Balady' bread. Olaoye et al. (2006), determined the sensory qualities of breads produced from varying substitutions of soybean and plantain flours as composites of wheat flour. the sensory evaluation showed that, insignificant differences were observed between the whole wheat bread and the 5\% soybean supplement in the sensory attributes of aroma, internal texture, taste and general acceptability. Dhingra and Jood (2004), studied the effect of supplementation on the functional, baking and organoleptic characteristics of bread. The bread volume decreased with increasing amount of non-wheat flour substitution. The crumb color changed from creamish white to dull brown and a gradual hardening of crumb texture was observed as the addition of soybean (full-fat and defatted) and barley flours increased. It may be concluded that the substitution of wheat flour with soybean and barley flour up to an amount equivalent to $10 \%$ of full-fat and defatted soyflour, $15 \%$ for barley flour, full-fat soy + barley flour and defatted soy + barley flour produced acceptable bread loaves with good organoleptic characteristics.Hooda and Jood (2005), developed wheat-fenugreek-based health bread.
They found that, additions of fenugreek (raw, soaked and germinated) up to the level of 15 per cent produced bread with a satisfactory loaf volume and other sensory quality attributes (crumb color, crumb texture, taste etc.), whereas the 20 per cent level of supplementation caused a depression effect in loaf volume and the breads were found to be bitter in taste. Eissa et al. (2007)found that, baking properties, color and sensory evaluation tests showed that $15 \%$ of wheat flour could be replaced with germinated legumes and mushroom flours and still providing good quality of Egyptian balady bread and biscuits. Staling test revealed that wheat bread was better than wheat-germinated legumes and mushroom flours bread regarding freshness. Butt et al. (2011), reached that, bread volume decreased with increasing the cowpea flour substitution, while, the loaf weight increased. Substitution of wheat flour with cowpea flour also affected the sensory characteristics of bread. At the higher level, the acceptability of the bread decreased as the structure of the bread become compact at higher level of substitution. Replacement of wheat flour with cowpea flour up to $10 \%$ of substitution level produced acceptable bread. Mohammed et al. (2012), evaluated the effect of chickpea addition at different concentration on wheat bread characteristics. Baking tests showed that, chickpea addition with $<20 \%$ significantly impaired the volume, internal structure and texture of the breads. The bread had a strongly brown color, a hard crust, and was unacceptable to consumers. Supplementing wheat-bread with chickpea at 10 to $>20 \%$ flour also was acceptable. Roberts et al. (2012), showed that Fenugreek gum (extruded and non-extruded) was substituted for wheat flour at $0 \%, 5 \%$ and $10 \%(\mathrm{w} / \mathrm{w})$ and the rheological effects and bread making characteristics. They found that, the substitution of FG into bread dough at levels of $10 \%$ caused detrimental results to baked bread volume, texture and the general appearance. Srivastava et al. (2012) studied the effect of incorporation of fenugreek seed husk (FSH) in muffins at different levels of 5, 10 and $15 \%$. Supplementation with FSH resulted in softer crumb texture indicated by the hardness which decreased in hardness (4.20 to $3.19 \mathrm{~N})$. Inclusion of FSH addition in muffins found acceptance by panelists with a rating better than the control. The optimal level of incorporation of FSH flour, based on sensory quality in muffins was found to be $10 \%$.Kasaye et al. (2015), showed that the flour of fenugreek supplemented at 5, 10 and $15 \%$ levels with wheat flour was assessed to produce bread. The sensory evaluation of products has exhibited that 5 and $10 \%$ for bread and 5\% for biscuit, fermented fenugreek flour supplemented with wheat flour resulted highly acceptable bread and biscuit compared with control samples. Wani et al. (2016),reached that, pulse flour up to $15 \%$ can be incorporated in wheat flour to produce acceptable chapattis with comparable overall accept- 
ability compared to whole wheat flour. Besides composite flours have lower setback viscosity which suggests that composite flour chapattis will maintain freshness for longer periods compared to control wheat flour.

As for stalling of bread, Axford et al. (1968), showed that loaf specific volume is a major factor in determining both the rate and extent of staling, both of which decrease in a linear manner, over the range studied, as loaf volume increases. The influence of changes in loaf specific volume on staling characteristics is greater in bread prepared by bulk fermentation than in bread prepared by the Chorleywood Bread Process. Bread made by the Chorleywood Bread Process stales less rapidly than bread made by the conventional bulk fermentation process. The effect of loaf specific volume on the rate of staling is more marked as the storage temperature is lowered. Qarooni et al. (1987), developed a baking test procedure has been developed after investigation of processing variables such as baking absorption, mixing time and sheeting thickness. The procedure, and its associated scoring system, have an adequate precision and are relevant to commercial baking methods and consumer taste in the Middle East.Baker et al. (1988), examined the effect of 5,10,15, 20, 25 and $30 \%$ compression depths on the sensitivity of the data and the characteristics of the Instron curve. They resulted that as the bread crumb aged, the amount of force required to compress the crumb increased. The greatest increase in force over the seven-day storage period was between days 1 and 4 after baking. The crumb firmness also increased as the degree of compression increased. Some variability in the data is desirable since it indicates sensitivity to changes in crumb firmness either due to staling or formulation. However, this should not be the only factor used to determine the appropriate compression depth. Sidhu et al. (1997), showed that, the amount of soluble starch and amylose contents also decreased significantly as the bread aged during storage. Despite their limitation, sensory analysis parameters were found to follow the staling of white as well as extra bran Arabic bread more closely than any other single method. Instron Puncture force measurements correlated well with other chemical methods and sensory analysis parameters in white arabic bread but did not provide significant correlations for extra bran Arabic bread. Gray and Bemiller (2003), reached a conclusion that, bread staling is a complex phenomenon in which multiple mechanisms operate. Polymer crystallizations with the formation of super molecular structures are certainly involved. The most plausible hypothesis is that, retrogradation of amylopectin occurs, and because water molecules are incorporated into the crystallites, the distribu- tion of water is shifted from gluten to starch/ amylopectin, thereby changing the nature of the gluten network. The role of additives may be to change the nature of starch protein molecules, to function as plasticizers, and/or to retard the redistribution of water between components. they added that, nothing more definite can be concluded at this time. Różyło and Laskowski (2011), evaluated the predictive power of flour and dough alveograph properties in simultaneous determination of bread loaf volume and crumb texture. They used ten Polish spring wheat cultivars. They showed that, from the experimental tests indicated that among the variables, the flour protein content, the Zeleny sedimentation index, the flour falling number, and dough strength were the main factors affecting the textural properties of the breadcrumb alone and with the bread loaf volume. The results showed that a combination of several flour and dough alveograph properties could predict bread quality. Fadda et al. (2014), confirmed the central role of amylopectin retrogradation and water redistribution within the different polymers in determining bread staling, but also highlighted the importance of other flour constituents, such as proteins and non-starch polysaccharides. Data obtained with thermal, spectroscopy, nuclear magnetic resonance, X-ray crystallography, and colorimetry analysis have pointed out the need to encourage the use of one or more of these techniques in order to better understand the mechanisms of staling. Results so far, obtained have provided new insight on bread staling, but the phenomenon has not been fully elucidated so far.

The recent study was carried out to determining bread quality as sensory panel and stalling abilities of breads produced from variable substitutions of rice, sorghum andnaked barley flours to flours of Egyptian wheat cultivars.

\section{MATERIALS AND METHODS}

The recent study included studying the possibility of substituting local cereals flours (rice, sorghum and naked barley) to local bread wheat cultivars. Adding fenugreek local pulse flour and imported soybean flour to improve characters of bread was also included. Separate experiments were carried out for each bread wheat variety. The studied local bread wheat cultivars were Misr2, Giza171 and Gemmiza11. Row materials for local cereals, fenugreek and bread wheat cultivars were obtained from Agricultural Research Center. Ministry of Agriculture, Giza, Egypt.86\% extraction flour were prepared by following AACC;26-10 A method. Tempered cleaned grains milled by barabender quadrumat mill using the barabender procedure. For each local bread wheat cultivars, the following flour blends were prepared (Table1). 
Table1; list of studied flour blends that represent different levels of local cereals flour substitution and pulse flour addition

\begin{tabular}{|c|c|c|c|c|}
\hline \multirow{2}{*}{ Code } & \multirow{2}{*}{ Treatment } & \multicolumn{3}{|c|}{ Component of one kilogram blended flour } \\
\hline & & wheat & cereal & pulse \\
\hline 1 & WF $100 \%$ & 1000 & - & - \\
\hline 2 & $\mathrm{WF}+10 \% \mathrm{RF}$ & 900 & 100 & - \\
\hline 3 & $\mathrm{WF}+10 \% \mathrm{RF}+5 \% \mathrm{Fen}$ & 850 & 100 & 50 \\
\hline 4 & $\mathrm{WF}+10 \% \mathrm{RF}+5 \%$ So & 850 & 100 & 50 \\
\hline 5 & $\mathrm{WF}+20 \% \mathrm{RF}$ & 800 & 200 & - \\
\hline 6 & $\mathrm{WF}+20 \% \mathrm{RF}+5 \% \mathrm{Fen}$ & 750 & 200 & 50 \\
\hline 7 & $\mathrm{WF}+20 \% \mathrm{RF}+5 \%$ So & 750 & 200 & 50 \\
\hline 8 & $\mathrm{WF}+30 \% \mathrm{RF}$ & 700 & 300 & - \\
\hline 9 & $\mathrm{WF}+30 \% \mathrm{RF}+5 \% \mathrm{Fen}$ & 650 & 300 & 50 \\
\hline 10 & $\mathrm{WF}+30 \% \mathrm{RF}+5 \%$ So & 650 & 300 & 50 \\
\hline 11 & $\mathrm{WF}+10 \% \mathrm{SF}$ & 900 & 100 & - \\
\hline 12 & $\mathrm{WF}+10 \% \mathrm{SF}+5 \% \mathrm{Fen}$ & 850 & 100 & 50 \\
\hline 13 & $\mathrm{WF}+10 \% \mathrm{Sf}+5 \%$ So & 850 & 100 & 50 \\
\hline 14 & $\mathrm{WF}+20 \% \mathrm{SF}$ & 800 & 200 & - \\
\hline 15 & $\mathrm{WF}+20 \% \mathrm{SF}+5 \% \mathrm{Fen}$ & 750 & 200 & 50 \\
\hline 16 & $\mathrm{WF}+20 \% \mathrm{SF}+5 \%$ So & 750 & 200 & 50 \\
\hline 17 & $\mathrm{WF}+30 \% \mathrm{SF}$ & 700 & 300 & - \\
\hline 18 & $\mathrm{WF}+30 \% \mathrm{SF}+5 \% \mathrm{Fen}$ & 650 & 300 & 50 \\
\hline 19 & $\mathrm{WF}+30 \% \mathrm{SF}+5 \%$ So & 650 & 300 & 50 \\
\hline 20 & $\mathrm{WF}+10 \% \mathrm{BF}$ & 900 & 100 & - \\
\hline 21 & $\mathrm{WF}+10 \% \mathrm{BF}+5 \% \mathrm{Fen}$ & 850 & 100 & 50 \\
\hline 22 & $\mathrm{WF}+10 \% \mathrm{BF}+5 \%$ So & 850 & 100 & 50 \\
\hline 23 & $\mathrm{WF}+20 \% \mathrm{BF}$ & 800 & 200 & - \\
\hline 24 & $\mathrm{WF}+20 \% \mathrm{BF}+5 \%$ Fen & 750 & 200 & 50 \\
\hline 25 & $\mathrm{WF}+20 \% \mathrm{BF}+5 \%$ So & 750 & 200 & 50 \\
\hline 26 & $\mathrm{WF}+30 \% \mathrm{BF}$ & 700 & 300 & - \\
\hline 27 & $\mathrm{WF}+30 \% \mathrm{BF}+5 \%$ Fen & 650 & 300 & 50 \\
\hline 28 & $\mathrm{WF}+30 \% \mathrm{BF}+5 \%$ So & 650 & 300 & 50 \\
\hline 29 & $\mathrm{WF}+5 \% \mathrm{Fen}$ & 950 & - & 50 \\
\hline 30 & $\mathrm{WF}+5 \%$ So & 950 & - & 50 \\
\hline 31 & $\mathrm{WF}+5 \% \mathrm{Fen}+5 \%$ So & 900 & - & 100 \\
\hline
\end{tabular}

WF; Wheat flour

BF; Barley flour

\section{Bread quality:}

For each studied flour blend of each bread wheat cultivar, the following procedure was followed during dough preparation and baking to measure bread parameters (loaf diameter before baking, loaf diameter after baking and loaf weight after baking );

Dough comprising flour (200g) compressed yeast $(2 \mathrm{~g})$, salt $(3 \mathrm{~g})$ and various(amounts of water were mixed using) Brabender, after mixing, dough were placed in sealed plastic containers and allowed to ferment at $30^{\circ} \mathrm{C}$

For one hour. After the bulk fermentation, dough were degassed by hand pressure and scaled off into three pieces of $100 \mathrm{gm}$. The dough pieces
SF; Sorghum flour

SO;Soybean flour

were rolled by hand into balls, placed on a wooden board previously dusted with flour, and covered with aplastic sheet to avoid surface drying and subsequent skin formation, these were left for 10 min at $28 \pm 2^{\circ} \mathrm{C}$ for intermediate proofing. The dough pieces were then hand-rolled to $10 \mathrm{~mm}$ thickness using a spacing guide, after which they were passed twice through apair of steel rollers. The sheeted doughs were placed on wooden boards lightly dusted with flour for final proofing at $28 \pm 2^{\circ} \mathrm{C} 65 \pm 5 \%$ r.h. for $30 \mathrm{mi}$. Oven temperature was set at $400^{\circ} \mathrm{C}$ and baking was carried out for (90S) ona preheated aluminum tray. This combination of temperature and time is the most widely used in commercial practice and thus was selected for this technique. 


\section{Yeast;}

Active instant yeast, imported from Turkey, packed under vacuum (450g per pack), as wellas fresh compressed yeast, produced locally by sugar and integrated industries company and starch and yeast company was used for Balady Bread production.

\section{Experienced panelist evaluation:}

Loaves were weighed and diameter of each loaf was measured. Average of both weight and diameter for each samples were calculated then, loaves were ranked based on consumer preferences, which was determined as described by (Qarooni et al.1987). The scoring of the Balady Arabic bread was carried out on a numerical basis. The marks for each quality parameter were assigned according to consumer preference (Table 2).

Table (2); Loaf scoring for Balady Bread:

\begin{tabular}{|l|c|}
\hline Quality factors & Score \\
\hline Crust smoothness & 5 \\
\hline Shape & 7 \\
\hline Crust colour & 8 \\
\hline Ability to roll and fold & 10 \\
\hline Quality of separation & 16 \\
\hline Evenness of layers & 5 \\
\hline
\end{tabular}

Cited after: Qarooni et al, 1987. Journal of cereal science.

\section{Description of quality parameters: \\ - Crust Smoothness: (5 Marks)}

Ideal Balady Bread should have a smooth top and bottom crust. Marks are allocated according to degree of smoothness.

\section{- (Crust color) (5 Marks);}

The ideal Balady Bread should have a light brown color; hence marks are deducted for increasing darkness (over-baked) of the crust of having pale color (under-baked). Scores are allocated based on subjective assessment of this parameter.

- Shape (7 Marks);

Represent the final bread shape. The highest score is given to round loaves, with points being gradually deducted for increasing lack of symmetry.

\section{- Ability to roll and fold (10Marks);}

Ideally evaluation, bread should be able to with stand either rolling or folding without cracking or breaking. Cracking whilst folding limits the filling ability and it is considered extremely undesirable. The assessment of this property after one day allows the effect of stalling to be observed.

- Quality of separation (16 Marks);

This is the single most important parameter. Apart from the periphery, the top and bottom layers should be completely separated from each other. Breads without complete separation of the layers are unacceptable and hence, are downgraded.
- Evenness of the layers (5Marks);

The ideal bread should have upper and lower layers of equal and uniform thickness.

\section{Bread Stalling}

Bread loaves for each flour blend sample were cooled, bagged in polyethylene and stored at room temperature. Data for bread stalling were recorded by texture testing procedure after one, three and five days of storage as follows:

One slice of bread $25 \mathrm{~mm}$ thick or two slices, each $12.5 \mathrm{~mm}$ thick were used. The slices were cut mechanically or by hand provided the end three slices are discarded and the crusts are not removed. A38.1mm Øprobe (TA4/1000) at test speed of $2 \mathrm{~mm} / \mathrm{Sec}$. The location of testing is the center of the bread slice (S) avoiding non-representative areas of crumb. Sample is subjected to $40 \%$ deformation and compression load at $25 \%$ deformation was recorded in either Newton's or g. Test was made to a total of three samples per loaf.

Experiments were carried out during the period from 2016 to 2018 in labs of the faculty of Agriculture (El-Shatby), Alexandria University. Statistical analysis was carried out for each separate wheat cultivar blends as a randomized complete block design with three replicates. Combined analysis over experiments was performed when the assumptions of homogeneity of variances cannot be rejected. Stalling test was performed at three successive dates (dayone, day three and day five). Hardness was measured on three replicates per blend. Combined analysis over days was performed. (Gomez and Gomez,1988).

\section{RESULTS AND DISCUSSIONS}

The main objective of the recent study was to assess the possibility of substituting local cereals flours represented by rice, sorghum and naked barley to wheat flour. Three separate experiments were carried out each included one of the local bread wheat varieties. These were Misr2, Giza171 and Gimmiza11. Combined analysis of experiments (cultivars) was performed. Since, the assumption of homogeneity of variances was not rejected. The obtained results were presented for bread quality and stalling test.

\section{Sensory panel for breads:}

Sensory analysis was carried out in a sensory evaluation procedure compliant with the international standards (ISO 8589, 2007). In order to describe the sensory properties of the thirty-one types of bread, the sensory profiling method was applied (ISO $13299,2003)$. This method consisted of two phases, an initial phase to select, train and validate the assessors and a subsequent phase focused on the evaluation of the samples. The evaluation characters included crust smoothness, shape, crust color, cracks, blisters, ability to roll and fold, quality of separation, evenness of layers, grain appearance, grain uniformity and crumb color. Numerical grades were transformed before statistical analysis. Table 3 presented the analysis of variance for sensory panel characters 
of breads cultivars, significantly varied only in loaves shapes, whereas, other characters showed insignificant differences among the studied cultivars. Breads significantly varied in crust smoothness, shape, crust color, ability to roll, quality of separation, evenness of

\begin{tabular}{|l|l|l|l|l|l|l|l|}
\hline \multirow{2}{*}{ S.O.V. } & \multirow{2}{*}{ d.f. } & \multicolumn{6}{|c|}{ M.S. } \\
\cline { 3 - 8 } & & $\begin{array}{c}\text { Crust } \\
\text { smoothness }\end{array}$ & Shape & $\begin{array}{c}\text { Crust } \\
\text { colour }\end{array}$ & $\begin{array}{c}\text { Ability to roil } \\
\text { and fold }\end{array}$ & $\begin{array}{c}\text { Quality of } \\
\text { separation }\end{array}$ & $\begin{array}{c}\text { Evenness of } \\
\text { layers }\end{array}$ \\
\hline Cultivar (A) & 2 & $2.950^{\text {n.s }}$ & $7.527^{* *}$ & $6.068^{\text {n.s }}$ & $43.681^{\text {n.s }}$ & $13.950^{\text {n.s }}$ & $0.720^{\text {n.s }}$ \\
\hline Error & 4 & 0.154 & 0.022 & 0.278 & 1.165 & 2.616 & 0.414 \\
\hline Treatments (B) & 30 & $1.224^{* *}$ & $1.773^{* *}$ & $2.425^{* *}$ & $3.243^{* *}$ & $7.066^{* *}$ & $1.369^{* *}$ \\
\hline A*B & 60 & $1.072^{* *}$ & $1.390^{* *}$ & $1.638^{* *}$ & $4.196^{* *}$ & $6.431^{* *}$ & $1.139^{* *}$ \\
\hline Error & 180 & 0.356 & 0.375 & 0.578 & 0.680 & 1.489 & 0.389 \\
\hline
\end{tabular}

**, indicate significance at 0.01 level.

\section{Crust smoothness:}

Ideal balady bread is evaluated by five points for crust smoothness. Orthogonal comparisons between different levels of rice flour substitution to wheat flour reflected on crust smoothness score for the studied flour blends were shown in Table 4. A significant rise in crust smoothness score was obtained when rice layers and grain appearance (seven characters out of twelve studied characters). Wheat cultivar $\times$ blends interaction significantly varied in all sensory panel characters, except for, blister and quality of tearing.

Table 4: Orthogonal comparisons between different levels of rice flour substitution to wheat flour reflected on Crust smoothness score for the studied flour blends.

\begin{tabular}{|l|c|c|c|c|c|c|}
\hline \multirow{2}{*}{ Comparisons } & \multicolumn{5}{|c|}{ Wheat cultivar } \\
\cline { 2 - 7 } & \multicolumn{2}{|c|}{ Misr2 } & \multicolumn{2}{c|}{ Giza171 } & \multicolumn{2}{c|}{ Gimmeza11 } \\
\cline { 2 - 7 } & Effect & Significance & Effect & Significance & Effect & Significance \\
\hline $\begin{array}{l}\text { WF+ 10\% RF v.s } \\
\text { WF+20\% RF }\end{array}$ & 0.556 & 0.001 & -0.611 & 0.000 & -0.333 & 0.006 \\
\hline $\begin{array}{l}\text { WF+ 20\% RF v.s } \\
\text { WF+30\%RF }\end{array}$ & 0.000 & 0.000 & 0.111 & 0.578 & 0.333 & 0.006 \\
\hline
\end{tabular}

WF; Wheat Flour

RF; Rice Flour

Fen; Fenugreek Flour

Soy; Soybean flour

Substitution by sorghum flour at $10 \%$ level improved crust smoothness score compared with $20 \%$ level of substitution to Misr2 wheat flour. That improvement had not reached the level of significance. Increasing the level of sorghum flour substitution from 10 to $20 \%$ of Giza171 or Gimmeza11 wheat flours resulted in lower score of crust smoothness. That reduction in crust smoothness score reached the level of significance only with Gimmeza11 wheat flour. The only significant reduction in crust smoothness associated with raising the level of sorghum flour substitution from 20 to $30 \%$ was noticed with Misr2 wheat flour. Gimmeza11 wheat flour substituted with $30 \%$ sorghum flour obtained lower crust smoothness score relative to $20 \%$ level of substitution (Table 5).

Table 5: Orthogonal comparisons between different levels of sorghum flour substitution to wheat flour reflected on Crust smoothness for the studied flour blends

\begin{tabular}{|l|c|c|c|c|c|c|}
\hline \multirow{2}{*}{\multicolumn{1}{|c|}{ Comparisons }} & \multicolumn{4}{|c|}{ Wheat cultivar } \\
\cline { 2 - 7 } & \multicolumn{2}{|c|}{ Misr2 } & \multicolumn{2}{c|}{ Giza171 } & \multicolumn{2}{c|}{ Gimmeza11 } \\
\cline { 2 - 7 } & Effect & Significance & Effect & Significance & Effect & Significance \\
\hline $\begin{array}{l}\text { WF+ 10\% SF v.s } \\
\text { WF+20\% SF }\end{array}$ & 0.278 & 0.081 & -0.167 & 0.259 & -0.278 & 0.020 \\
\hline $\begin{array}{l}\text { WF+ 20\%SF v.s } \\
\text { WF+30\%SF }\end{array}$ & -0.556 & 0.001 & -0.167 & 0.259 & 0.222 & 0.060 \\
\hline
\end{tabular}

WF; Wheat Flour $\quad$ RF; Rice Flour $\quad$ Fen; Fenugreek Flour $\quad$ Soy; Soybean flour 
Like what noticed with sorghum flour substitution, barley flour substitution to Misr2 wheat flour at $20 \%$ level was associated with lower score of crust smoothness, although had not reached the level of significance. Meanwhile, barley flour substitution to Giza171 or Gimmeza11 flour at $20 \%$ level showed significant lower crust smoothness score relative to $10 \%$ level. Also, raising the level of barley flour substitution to $30 \%$ of Misr2 wheat flour gave a significant reduction in crust smoothness score. The same was true with Giza171 wheat flour, although, had not reached the level of significance. The opposite was obtained with Gimmeza11 wheat flour, since, $20 \%$ barley flour substitution significantly surpassed $30 \%$ level (Table 6).

Table 6: Orthogonal comparisons between different levels of barley flour substitution to wheat flour reflected on Crust smoothness score of the studied flour blends.

\begin{tabular}{|c|c|c|c|c|c|c|}
\hline \multirow{3}{*}{ Comparisons } & \multicolumn{6}{|c|}{ Wheat cultivar } \\
\hline & \multicolumn{2}{|c|}{ Misr2 } & \multicolumn{2}{|c|}{ Giza171 } & \multicolumn{2}{|c|}{ Gimmeza11 } \\
\hline & Effect & Significance & Effect & Significance & Effect & Significance \\
\hline $\begin{array}{l}\mathrm{WF}+10 \% \mathrm{BF} v \cdot s \\
\mathrm{WF}+20 \% \mathrm{BF}\end{array}$ & 0.278 & 0.081 & -0.333 & 0.026 & -0.611 & 0.000 \\
\hline $\begin{array}{l}\mathrm{WF}+20 \% \mathrm{BF} v \cdot s \\
\mathrm{WF}+30 \% \mathrm{BF}\end{array}$ & -0.389 & 0.016 & -0.056 & 0.145 & 0.500 & 0.000 \\
\hline
\end{tabular}

WF; Wheat Flour RF; Rice Flour

Comparison between substitution cereal flours, showed that, rice flour as a replacer to Misr2 flour in comparison to sorghum flour blends gave significantly lower score of crust smoothness ( $\mathrm{p} \geq 0.04)$. Meanwhile, rice flour $v s$. sorghum flour as a replacer to Giza171 or Gimmeza11 wheat cultivars obtained higher crust smoothness score, although was only
Fen; Fenugreek Flour Soy; Soybean flour significant with Giza171 wheat flour blends. Comparison between wheat flour blends with rice flour versus those with barley flour, showed a superiority of the former over the latter in crust smoothness, although had not reached the level of significance in any of Misr2 or Gimmeza11 wheat flours (Table 7).

Table 7: Orthogonal comparison for the effect of pulse flours supplementation to wheat /local cereals flours on Crust smoothness of flour blend.

\begin{tabular}{|l|c|c|c|c|c|c|}
\hline \multirow{2}{*}{ Comparisons } & \multicolumn{5}{|c|}{ Wheat cultivar } & \multicolumn{2}{c|}{ Gimmeza11 } \\
\cline { 2 - 7 } & \multicolumn{2}{|c|}{ Misr2 } & \multicolumn{2}{c|}{ Giza171 } & Significance \\
\cline { 2 - 7 } & Effect & Significance & Effect & Significance & Effect & Signe \\
\hline $\begin{array}{l}\text { WF+ R Fv.s } \\
\text { WF+SF }\end{array}$ & 0.019 & 0.042 & -0.019 & 0.048 & -0.111 & 0.102 \\
\hline $\begin{array}{l}\text { WF +RF v.s } \\
\text { WF+ BF }\end{array}$ & 0.130 & 0.157 & -0.148 & 0.084 & 0.037 & 0.306 \\
\hline
\end{tabular}

WF; Wheat Flour RF; Rice Flour

The role of pulses flour substitution to cereals/wheat flour blends was presented in Table 8 . Comparison between flour blends of cereals and fenugreek flour versus those with soybean flour cleared that fenugreek flour blends gave higher crust smoothness score with Misr2, Giza171 and Gimmeza11 wheat flours, with significance for Giza171 blend. Also, wheat flour blends with both
Fen; Fenugreek Flour Soy; Soybean flour of fenugreek and soybean flours obtained higher crust smoothness score than those had fenugreek flour with all studied wheat flour cultivars. Similar effect was obtained when blends contained both fenugreek and soybean flours was compared with those contained soybean flour only, expect for blends of Giza171 wheat flour.

Table 8: Orthogonal comparison for the effect of pulse flours supplementation to wheat/local cereals flours on crust smoothness of flour blend

\begin{tabular}{|l|l|l|l|l|l|l|}
\hline \multirow{2}{*}{ Comparisons } & \multicolumn{3}{|c|}{ Wheat cultivar } \\
\cline { 2 - 7 } & \multicolumn{2}{|c|}{ Misr2 } & \multicolumn{2}{c|}{ Giza171 } & \multicolumn{2}{c|}{ Gimmeza11 } \\
\cline { 2 - 7 } & Effect & Significance & Effect & Significance & Effect & Significance \\
\hline $\begin{array}{l}\text { WF+ (RF, SF, BF)+Fen } v s . \\
\text { WF+(RF,SF,BF)+SO }\end{array}$ & 0.133 & 0.125 & 0.233 & 0.005 & 0.117 & 0.071 \\
\hline $\begin{array}{l}\text { WF +Fen +SO vs. } \\
\text { WF + Fen }\end{array}$ & 0.094 & 0.013 & 0.003 & 0.008 & 0.058 & 0.038 \\
\hline $\begin{array}{l}\text { WF+ Fen+ SO } v s . \\
\text { WF+SO }\end{array}$ & 0.070 & 0.062 & -0.039 & 0.253 & 0.036 & 0.184 \\
\hline
\end{tabular}




\section{Shape of loaves:}

Shape of loaves was evaluated as the highest score in given to round loaves, with points being gradually deducted for increasing lack of symmetry. Orthogonal comparisons between levels of rice flour substitution to wheat flour reflected on shape of loaves for the studied flour blends were presented in Table 9. Increasing the level of rice flour substitution from 10 to $20 \%$ of Misr2 wheat flour, reduced loaves shape. While increasing the level of substitution to $30 \%$ of wheat flour gave insignificant positive effect on shape. Giza171 and Gimmeza11 wheat flours, responded differently, where, loaves shape scores were significantly reduced when rice flour substitution increased from 10 to $20 \%$ and vas vers when rice flour increased from 20 to $30 \%$.

Table 9: Orthogonal comparisons between different levels of rice flour substitution to wheat flour reflected on shape of loaves for the studied flour blends.

\begin{tabular}{|l|l|l|l|l|l|l|}
\hline \multirow{2}{*}{ Comparisons } & \multicolumn{5}{|c|}{ Wheat cultivar } \\
\cline { 2 - 7 } & \multicolumn{2}{|c|}{ Misr2 } & \multicolumn{2}{c|}{ Giza171 } & \multicolumn{2}{c|}{ Gimmeza11 } \\
\cline { 2 - 7 } & Effect & Significance & Effect & Significance & Effect & Significance \\
\hline $\begin{array}{l}\text { WF+ 10\% RF v.s } \\
\text { WF+20\% RF }\end{array}$ & 0.667 & 0.001 & -0.611 & 0.000 & -0.500 & 0.000 \\
\hline $\begin{array}{l}\text { WF+ 20\% RF v.s } \\
\text { WF+30\%RF }\end{array}$ & -0.222 & 0.238 & 0.667 & 0.000 & 0.278 & 0.003 \\
\hline
\end{tabular}

WF; Wheat Flour RF; Rice Flour

Effect of sorghum flour substitution to wheat flours at variable percentages on recorded scores for loaves shape was illustrated on Table 10. Misr2 wheat flour, substituted with $10 \%$ sorghum flour enjoyed larger loaves shape in comparison to $20 \%$ level of replacement. Another deduction in loaves shape symmetry was obtained with increasing sorghum flour replacement level to $30 \%$ of wheat flour. In Giza171 wheat flours, increasing sorghum flour substitution level from 10 to 20 or from 20 to
Fen; Fenugreek Flour Soy; Soybean flour

$30 \%$ were proportional to lack of symmetry in loaves shape, although, that deduction was only significant with increasing substitution level from 20 to $30 \%$. Gimmeza11 wheat flour respond oppositely to Misr2 wheat flour, since, loaves shape symmetry reduced with increasing sorghum flour replacement from 10 to $20 \%$, but with increasing the level of substitution to $30 \%$, symmetry of loaves improved.

Table 10: Orthogonal comparisons between different levels of sorghum flour substitution to wheat flour reflected on loaves shape of the flour blend.

\begin{tabular}{|c|c|c|c|c|c|c|}
\hline \multirow{3}{*}{ Comparisons } & \multicolumn{6}{|c|}{ Wheat cultivar } \\
\hline & \multicolumn{2}{|c|}{ Misr 2} & \multicolumn{2}{|c|}{ Giza171 } & \multicolumn{2}{|c|}{ Gimmeza11 } \\
\hline & Effect & Significance & Effect & Significance & Effect & Significance \\
\hline $\begin{array}{l}\mathrm{WF}+10 \% \mathrm{SF} v . s \\
\mathrm{WF}+20 \% \mathrm{SF}\end{array}$ & 0.556 & 0.004 & -0.056 & 0.157 & -0.667 & 0.000 \\
\hline $\begin{array}{l}\mathrm{WF}+20 \% \mathrm{SF} v . s \\
\mathrm{WF}+30 \% \mathrm{SF}\end{array}$ & -0.667 & 0.001 & -0.278 & 0.052 & 0.500 & 0.000 \\
\hline
\end{tabular}

WF; Wheat Flour RF; Rice Flour

Orthogonal comparisons between levels of barley flour replacement to wheat flour and its reflection on shape symmetry of loaves was shown in Table 11. Loaves made from Misr2 wheat flour blends that included $20 \%$ barley flour had higher loaves shape symmetry at significant. While, increasing the level if barley flour replacement from 20 to $30 \%$ of wheat flour gave immeasurable effect on loaves shape symmetry. Giza171 wheat flour replaced by $20 \%$ barley flour was associated with
Fen; Fenugreek Flour Soy; Soybean flour

insignificant increase in loaves shape symmetry. Meanwhile, increasing barley flour replacement level to $30 \%$ significantly $(\mathrm{p} \geq 0.05)$ deduced the loaves shape symmetry. Gimmeza11 wheat flour, replaced by $20 \%$ barley flour, had significantly less shape symmetry relative to blend with $10 \%$ barley flour. Meanwhile, the difference in loaves shape with increasing the level of barley flour from 20 to $30 \%$ was immeasurable. 
Table 11: Orthogonal comparisons between different levels of barley flour substitution to wheat flour reflected on shapesymmetry of loaves of the flour blend.

\begin{tabular}{|l|l|l|l|l|l|l|}
\hline \multirow{2}{*}{ Comparisons } & \multicolumn{5}{|c|}{ Wheat cultivar } \\
\cline { 2 - 7 } & \multicolumn{2}{|c|}{ Misr2 } & \multicolumn{2}{c|}{ Giza171 } & \multicolumn{2}{c|}{ Gimmeza11 } \\
\cline { 2 - 7 } & Effect & Significance & Effect & Significance & Effect & Significance \\
\hline $\begin{array}{l}\text { WF+ 10\% BF v.s } \\
\text { WF+20\% BF }\end{array}$ & 0.056 & 0.089 & 0.222 & 0.118 & -0.500 & 0.000 \\
\hline $\begin{array}{l}\text { WF+ 20\%BF v.s } \\
\text { WF+30\%BF }\end{array}$ & 0.000 & 0.000 & -0.278 & 0.052 & -0.000 & 0.000 \\
\hline
\end{tabular}

WF; Wheat Flour RF; Rice Flour

Over all detailed flour blends, blend of Misr2 wheat flour with rice flour had significantly $(\mathrm{p} \geq 0.01)$ higher loaves shape symmetry than blends with sorghum flour. The same rice flour/Misr2 wheat flour blends surpassed blends with barley flour in loaves shape, although, that superiority had not reached the
Fen; Fenugreek Flour Soy; Soybean flour

significance level. Similar results were shown by Giza171 wheat flour blends. Whereas, Gimmeza11 wheat flour blends with rice flour were of less loaves shape symmetry than the corresponding blends with sorghum flour or barley flour (Table 12).

Table 12: Orthogonal comparison for the effect of pulse flours supplementation to wheat /local cereals flours on loaves shape symmetry of flour blend.

\begin{tabular}{|l|c|c|c|c|c|c|}
\hline \multirow{2}{*}{ Comparisons } & \multicolumn{5}{|c|}{ Wheat cultivar } \\
\cline { 2 - 7 } & \multicolumn{2}{|c|}{ Misr2 } & \multicolumn{2}{c|}{ Giza171 } & \multicolumn{2}{c|}{ Gimmeza11 } \\
\cline { 2 - 7 } & Effect & Significance & Effect & Significance & Effect & Significance \\
\hline $\begin{array}{l}\text { WF+RFv.s } \\
\text { WF+SF }\end{array}$ & -0.278 & 0,012 & -0.167 & 0.044 & 0.074 & 0.159 \\
\hline $\begin{array}{l}\text { WF +RF v.s } \\
\text { WF+ BF }\end{array}$ & -0.167 & 0,127 & -0.204 & 0.015 & 0.019 & 0.127 \\
\hline
\end{tabular}

\section{WF; Wheat Flour \\ RF; Rice Flour}

Pulse flour replacement to blends flour and its effect on loaves shape symmetry was presented in Table 13. Blends with soybean surpassed those with fenugreek in loaves shape symmetry in all studied wheat cultivars. That was more obvious from orthogonal comparison between blends contained fenugreek and soybean flours versus those with fenugreek flour only. The single role of fenu-

\section{Fen; Fenugreek Flour Soy; Soybean flour}

greek flour in wheat flour blends was expressed by the orthogonal comparison between flour blends that included fenugreek and soybean flour versus those contained soybean flour. The latter comparison assured that fenugreek flour in wheat flour blends resulted in higher loaves shape symmetry irrespective of the wheat cultivar.

Table 13: Orthogonal comparison for the effect of pulse flours supplementation to wheat /local cereals flours on loaves shape symmetryof flour blend

\begin{tabular}{|c|c|c|c|c|c|c|}
\hline \multirow{3}{*}{ Comparisons } & \multicolumn{6}{|c|}{ Wheat cultivar } \\
\hline & \multicolumn{2}{|c|}{ Misr2 } & \multicolumn{2}{|c|}{ Giza171 } & \multicolumn{2}{|c|}{ Gimmeza11 } \\
\hline & Effect & Significance & Effect & Significance & Effect & Significance \\
\hline $\begin{array}{l}\mathrm{WF}+(\mathrm{RF}, \mathrm{SF}, \mathrm{BF})+\mathrm{Fen} \\
v s . \mathrm{WF}+(\mathrm{RF}, \mathrm{SF}, \mathrm{BF})+\mathrm{SO}\end{array}$ & 0.133 & 0.197 & 0.150 & 0.055 & 0.217 & 0.000 \\
\hline $\begin{array}{l}\mathrm{WF}+\mathrm{Fen}+\mathrm{SO} v s \\
\mathrm{WF}+\text { Fen }\end{array}$ & 0.124 & 0.006 & 0.036 & 0.271 & 0.091 & 0.000 \\
\hline $\begin{array}{l}\mathrm{WF}+\mathrm{Fen}+\mathrm{SO} v s \\
\mathrm{WF}+\mathrm{SO}\end{array}$ & 0.100 & 0.025 & 0.009 & 0.077 & 0.052 & 0.017 \\
\hline
\end{tabular}

\section{Crust color:}

Ideal balady bread should have a light brown color. Marks are deductedfor increasing darkness (over baked) or having bale color(under baked). Misr2 wheat flour blend with $10 \%$ rice flour had darker loaves than blends with $20 \%$ rice flour. Meanwhile, opposite trend (lighter color or bale) were noticed with blends of Giza171 and Gimmeza11 cultivars with significant effect. In the meantime, blends of Misr2 wheat flour $+20 \%$ rice flour 
had lighter crust color than blends with $30 \%$ rice flour. Meanwhile, blends of Giza171 or Gimme- za11 wheat flours with $20 \%$ rice flour gave darker loaves than blends with $30 \%$ rice flour (Table 14).

Table 14: Orthogonal comparisons between different levels of rice flour substitution to wheat flour reflected on Crust color of the flour blend.

\begin{tabular}{|l|c|c|c|c|c|c|}
\hline \multirow{2}{*}{ Comparisons } & \multicolumn{3}{|c|}{ Wheat cultivar } \\
\cline { 2 - 7 } & \multicolumn{2}{|c|}{ Misr2 } & \multicolumn{2}{c|}{ Giza171 } & \multicolumn{2}{c|}{ Gimmeza11 } \\
\cline { 2 - 7 } & Effect & Significance & Effect & Significance & Effect & Significance \\
\hline $\begin{array}{l}\text { WF+ 10\% RF v.s } \\
\text { WF+20\% RF }\end{array}$ & 0.333 & 0.163 & -0.722 & 0.000 & -0.278 & 0.039 \\
\hline $\begin{array}{l}\text { WF+ 20\% RF v.s } \\
\text { WF+30\%RF }\end{array}$ & -0.333 & 0.163 & 0.222 & 0.151 & 0.722 & 0.000 \\
\hline
\end{tabular}

WF; Wheat Flour $\quad$ RF; Rice Flour

Orthogonal comparisons between wheat flour blends with sorghum flour expressed in crust color of loaves were illustrated in Table 15. Misr2 flour blends with $10 \%$ sorghum flour produced darker crust relative to blends with $20 \%$ sorghum flour. Meanwhile, the opposite was true with Giza171 and Gimmeza11 blends. Also, blends of Misr2

Fen; Fenugreek Flour Soy; Soybean flour

wheat flour with $20 \%$ sorghum flour gave lighter crust colour than loaves of blend with $30 \%$ sorghum flour. Also, vas vers were obtained with both of Giza171 and Gimmeza11 flour blends, where, darker loaves crust colour was obtained from blends with $20 \%$ sorghum flour than those contained 30\% sorghum flour (Table 15 ).

Table 15: Orthogonal comparisons between different levels of sorghum flour substitution to wheat flour reflected on Crust colour of the flour blend.

\begin{tabular}{|c|c|c|c|c|c|c|}
\hline \multirow{3}{*}{ Comparisons } & \multicolumn{6}{|c|}{ Wheat cultivar } \\
\hline & \multicolumn{2}{|r|}{ Misr2 } & \multicolumn{2}{|c|}{ Giza171 } & \multicolumn{2}{|c|}{ Gimmeza11 } \\
\hline & Effect & Significance & Effect & Significance & Effect & Significance \\
\hline $\begin{array}{l}\mathrm{WF}+10 \% \mathrm{SF} \\
\text { v.s } \mathrm{WF}+20 \% \mathrm{SF}\end{array}$ & 0.444 & 0.065 & -0.667 & 0.000 & -0.833 & 0.000 \\
\hline $\begin{array}{l}\mathrm{WF}+20 \% \mathrm{SF} \\
\text { v.s } \mathrm{WF}+30 \% \mathrm{SF}\end{array}$ & -0.611 & 0.012 & 0.278 & 0.074 & 0.389 & 0.004 \\
\hline
\end{tabular}

WF; Wheat Flour RF; Rice Flour

Comparisons between wheat flour blends with different levels of barley flour substitution reflected on crust color of leaves for the studied blends were presented in Table 16. Misr2 wheat flour blends with $10 \%$ barley flour exhibited darker crust color than those with $20 \%$ barley flour. While, Giza171 and Gimmeza11 wheat flour blend

\section{Fen; Fenugreek Flour Soy; Soybean flour} with $10 \%$ barley flour showed significantly lighter crust color. In the meantime, Misr2 wheat flour blends with $20 \%$ barley flour showed bale crust color than blends with $30 \%$ barley flour, while, Giza171 and Gimmeza11 flour blends with $20 \%$ barley flour gave significantly darker crust color.

Table 16: Orthogonal comparisons between different levels of barley flour substitution to wheat flour reflected on Crust color of the flour blend.

\begin{tabular}{|c|c|c|c|c|c|c|}
\hline \multirow{3}{*}{ Comparisons } & \multicolumn{6}{|c|}{ Wheat cultivar } \\
\hline & \multicolumn{2}{|c|}{ Misr2 } & \multicolumn{2}{|c|}{ Giza171 } & \multicolumn{2}{|c|}{ Gimmeza11 } \\
\hline & Effect & Significance & Effect & Significance & Effect & Significance \\
\hline $\begin{array}{l}\mathrm{WF}+10 \% \mathrm{BF} v \cdot s \\
\mathrm{WF}+20 \% \mathrm{BF}\end{array}$ & 0.167 & 0.498 & -0.556 & 0.001 & -0.833 & 0.000 \\
\hline $\begin{array}{l}\mathrm{WF}+20 \% \mathrm{BF} v \cdot s \\
\mathrm{WF}+30 \% \mathrm{BF}\end{array}$ & -0.389 & 0.105 & 0.500 & 0.002 & 0.944 & 0.000 \\
\hline
\end{tabular}

Comparisons that differentiate between the role of replacement as rice, sorghum or barley flours reflected on crust color of loaves were presented in Table 17. Rice flour substitution gave bale loaves crust color relative to sorghum flour in all studied three wheat cultivars. Also, loaves of rice flour blends had lighter crust color than those of blends with barley flour. 
Table 17: Orthogonal comparison for the effect of pulse flours supplementation to wheat /local cereals flours on Crust color of flour blend

\begin{tabular}{|l|c|c|c|c|c|c|}
\hline \multirow{2}{*}{ Comparisons } & \multicolumn{5}{|c|}{ Wheat cultivar } \\
\cline { 2 - 7 } & \multicolumn{2}{|c|}{ Misr2 } & \multicolumn{2}{c|}{ Giza171 } & \multicolumn{2}{c|}{ Gimmeza11 } \\
\cline { 2 - 7 } & Effect & Significance & Effect & Significance & Effect & Significance \\
\hline $\begin{array}{l}\text { WF+ R Fv.s } \\
\text { WF+SF }\end{array}$ & -0.296 & 0.034 & -0.278 & 0.003 & -0.093 & 0.238 \\
\hline $\begin{array}{l}\text { WF +RF } v . s \\
\text { WF+ BF }\end{array}$ & -0.407 & 0.004 & -0.463 & 0.000 & 0.093 & 0.228 \\
\hline
\end{tabular}

The effect of different pulse flour supplementation replacement on crust color of loaves for the studied flour blends were presented in Table 18.Misr2 wheat flour blends with any of the studied local cereals and fenugreek flour gave insignificant effect to crust color over similar blends with soybean flour. Meanwhile, Giza171 and Gimmeza11 flour blends with any of local cereals and fenugreek flour produced darker crust color than those of similar blends and soybean flour. To clarity the role of soybean flour to crust color, comparison between blend of wheat + fenugreek and soy- bean flours produced darker crust color, irrespective of the type of wheat flour cultivar, than loaves of wheat flour blends with fenugreek flour. Additionally, the single role of fenugreek flour in influencing crust color was manifested through the comparison between wheat flour blends with both fenugreek and soybean flour versus those of soybean flour only. The latter comparison showed that presence of fenugreek flour in the blend resulted in darker crumb color relative to blends with no fenugreek flour. This result match true with all studied wheat cultivars.

Table 18: Orthogonal comparison for the effect of pulse flours supplementation to wheat /local cereals flours on Crust colour of flour blend

\begin{tabular}{|c|c|c|c|c|c|c|}
\hline \multirow{3}{*}{ Comparisons } & \multicolumn{6}{|c|}{ Wheat cultivar } \\
\hline & \multicolumn{2}{|c|}{ Misr2 } & \multicolumn{2}{|c|}{ Giza171 } & \multicolumn{2}{|c|}{ Gimmeza11 } \\
\hline & Effect & Significance & Effect & Significance & Effect & Significance \\
\hline $\begin{array}{l}\mathrm{WF}+(\mathrm{RF}, \mathrm{SF}, \mathrm{BF})+\mathrm{Fen} \\
v s . \mathrm{WF}+(\mathrm{RF}, \mathrm{SF}, \mathrm{BF})+\mathrm{SO}\end{array}$ & -0.083 & 0.415 & 0.167 & 0.051 & 0.133 & 0.069 \\
\hline $\begin{array}{l}\mathrm{WF}+\mathrm{Fen}+\mathrm{SO} v s \\
\mathrm{WF}+\text { Fen }\end{array}$ & 0.115 & 0.041 & 0.109 & 0.003 & 0.064 & 0.043 \\
\hline $\begin{array}{l}\mathrm{WF}+\mathrm{Fen}+\mathrm{SO} v s \\
\mathrm{WF}+\mathrm{SO}\end{array}$ & 0.130 & 0.021 & 0.079 & 0.031 & 0.039 & 0.205 \\
\hline
\end{tabular}

\section{Ability to roll and fold:}

Ideal bread should be able to withstand either rolling or folding without cracking or breaking. Cracking whilst folding limits the filling ability and it is considered extremely undesirable. High quality is expressed by high evaluation Figures. Orthogonal comparison between wheat flour blends with $10 \%$ rice flour and those with 20 and $30 \%$ rice flour reflected on ability of loaf to roll and fold (Table 19), showed that, the ability of loaf texture to roll and fold was insignificantly increased when rice replacement was increased from 10 to $20 \%$ with wheat flours of Misr2 and Gimmeza11 cultivars. While, opposite trend was noticed with Giza171flour. Also, increasing rice percentage in blends from 20 to $30 \%$ increased the ability of loaves to roll and fold, only with Gimmeza11 cultivar, whereas, the effect with Misr2 and Giza171 was either unnoticeable or insignificant.

Table 19: Orthogonal comparisons between different levels of rice flour substitution to wheat flour reflected on ability of loaf to roll and fold for the studied flour blends.

\begin{tabular}{|l|l|l|l|l|l|l|}
\hline \multirow{2}{*}{\multicolumn{1}{|}{ Comparisons }} & \multicolumn{5}{|c|}{ Wheat cultivar } \\
\cline { 2 - 7 } & \multicolumn{2}{|c|}{ Misr2 } & \multicolumn{2}{c|}{ Giza171 } & \multicolumn{2}{c|}{ Gimmeza11 } \\
\cline { 2 - 7 } & Effect & Significance & Effect & Significance & Effect & Significance \\
\hline $\begin{array}{l}\text { WF+ 10\% RF v.s } \\
\text { WF+20\% RF }\end{array}$ & 0.167 & 0.675 & -0.333 & 0.167 & 0.167 & 0.183 \\
\hline $\begin{array}{l}\text { WF+ 20\% RF v.s } \\
\text { WF+30\%RF }\end{array}$ & -0.167 & 0.675 & -0.000 & 0.000 & 0.667 & 0.000 \\
\hline
\end{tabular}

WF; Wheat Flour

RF; Rice Flour

Fen; Fenugreek Flour

Soy; Soybean flour 
Sorghum flour substitution to wheat flour at variable percentage reflected on loaves ability to fold and roll was presented in Table 20. Ability to roll and fold was reduced with increasing sorghum flour substitution from 10 to $20 \%$ of the blends, irrespective of wheat cultivar. Also, that effect was significant only with Gimmeza11 wheat cultivar.
A substantial reduction in ability to roll and fold was associated with increasing sorghum percentage from 20 to $30 \%$ of Misr2 and Giza171 wheat cultivars blends. While, blends of Gimmeza11 wheat that had $30 \%$ sorghum flour gave loaves of higher ability to fold and roll.

Table 20: Orthogonal comparisons between different levels of sorghum flour substitution to wheat flour reflected on loaves ability to roll and fold for the studied flour blends.

\begin{tabular}{|l|l|l|l|l|l|l|}
\hline \multirow{2}{*}{ Comparisons } & \multicolumn{3}{|c|}{ Wheat cultivar } & \multicolumn{2}{c|}{ Gimmeza11 } \\
\cline { 2 - 7 } & \multicolumn{2}{|c|}{ Misr2 } & \multicolumn{2}{c|}{ Giza171 } & \multicolumn{2}{c|}{ Efignificance } \\
\cline { 2 - 7 } & Effect & Significance & Effect & Significance & Effect & Significany \\
\hline $\begin{array}{l}\text { WF+ 10\% SF v.s } \\
\text { WF+20\% SF }\end{array}$ & -0.167 & 0.675 & -0.278 & 0.248 & -0.611 & 0.000 \\
\hline $\begin{array}{l}\text { WF+ 20\% SF v.s } \\
\text { WF+30\%SF }\end{array}$ & -0.056 & 0.075 & -0.722 & 0.004 & 0.500 & 0.000 \\
\hline
\end{tabular}

WF; Wheat Flour $\quad$ RF; Rice Flour

Barley flour substitution at $20 \%$ of Misr 2 and Gimmeza11 wheat flours gave loaves of lower ability to fold and roll. Whereas, Giza171 wheat flour with $20 \%$ barley flour insignificantly produced loaves of better ability to roll and fold. While, increasing the level of barley flour substitu-
Fen; Fenugreek Flour Soy; Soybean flour tion to $30 \%$ of Misr2 and Giza171 wheat flours, reduced the ability of loaves to roll and fold. Opposite to that, blends of Gimmeza11 with $30 \%$ barley flour had significantly better ability to roll and fold (Table 21).

Table 21: Orthogonal comparisons between different levels of barley flour substitution to wheat flour reflected on ability to roll and fold of the flour blend.

\begin{tabular}{|l|c|c|c|c|c|c|}
\hline \multirow{2}{*}{ Comparisons } & \multicolumn{4}{|c|}{ Wheat cultivar } \\
\cline { 2 - 7 } & \multicolumn{2}{|c|}{ Misr2 } & \multicolumn{2}{|c|}{ Giza171 } & \multicolumn{2}{c|}{ Gimmeza11 } \\
\cline { 2 - 7 } & Effect & Significance & Effect & Significance & Effect & Significance \\
\hline $\begin{array}{l}\text { WF+ 10\% BF v.s } \\
\text { WF+20\% BF }\end{array}$ & -0.333 & 0.106 & 0.278 & 0.248 & -0.444 & 0.001 \\
\hline $\begin{array}{l}\text { WF+ 20\%BF v.s } \\
\text { WF+30\%BF }\end{array}$ & -1.222 & 0.000 & -0.667 & 0.007 & 0.611 & 0.000 \\
\hline
\end{tabular}

WF; Wheat Flour RF; Rice Flour

Comparisons between blends of different cereals substitution to wheat flour (Table 22) showed that blends with rice flour surpassed those with sorghum and barley flours in loaves ability to
Fen; Fenugreek Flour Soy; Soybean flour roll and fold, when substituted Misr2 or Giza171 wheat cultivars. In the meantime, Gimmeza11 blends with sorghum or barley flours surpassed those with rice flour in ability to roll and fold.

Table 22: Orthogonal comparison for the effect of cereal flours supplementation on loaves ability to roll and fold of the studied flour blends.

\begin{tabular}{|c|c|c|c|c|c|c|}
\hline \multirow{3}{*}{ Comparisons } & \multicolumn{6}{|c|}{ Wheat cultivar } \\
\hline & \multicolumn{2}{|c|}{ Misr2 } & \multicolumn{2}{|c|}{ Giza171 } & \multicolumn{2}{|c|}{ Gimmeza11 } \\
\hline & Effect & Significance & Effect & Significance & Effect & Significance \\
\hline $\mathrm{WF}+\mathrm{R} F v . s \mathrm{WF}+\mathrm{SF}$ & -0.130 & 0.273 & -0.481 & 0.001 & 0.259 & 0.001 \\
\hline $\mathrm{WF}+\mathrm{RF}$ v.s $\mathrm{WF}+\mathrm{BF}$ & -0.407 & 0.001 & -0.093 & 0.453 & 0.241 & 0.001 \\
\hline
\end{tabular}

\section{WF; Wheat Flour RF; Rice Flour}

Role of fenugreek flour supplementation in comparison to soybean flour in wheat/ cereal blends (Table 23), showed that loaves of blends contained soybean flour produced loaves of higher ability to roll and fold relative to those contained fenugreek flour.
Fen; Fenugreek Flour

Soy; Soybean flour

That was assured for all wheat cultivars. Also, the single role of fenugreek flour in effecting the loaves ability to roll and fold cleared that fenugreek flour in blend reduced the loaves ability to roll and fold, irrespective of the wheat cultivar. 
Table 23: Orthogonal comparison for the effect of pulse flours supplementation to wheat /local cereals flours on loaves ability to roll and fold of the studied flour blends.

\begin{tabular}{|l|l|l|l|l|l|l|}
\hline \multirow{2}{*}{ Comparisons } & \multicolumn{5}{|c|}{ Wheat cultivar } \\
\cline { 2 - 7 } & \multicolumn{2}{|c|}{ Misr2 } & \multicolumn{2}{c|}{ Giza171 } & \multicolumn{2}{c|}{ Gimmeza11 } \\
\cline { 2 - 7 } & Effect & Significance & Effect & Significance & Effect & Significance \\
\hline $\begin{array}{l}\text { WF+ (RF, SF, BF)+Fenvs. } \\
\text { WF+(RF,SF,BF)+SO }\end{array}$ & 0.233 & 0.040 & 0.317 & 0.018 & 0.133 & 0.054 \\
\hline $\begin{array}{l}\text { WF +Fen +SO } \\
v s . \text { WF + Fen }\end{array}$ & 0.048 & 0.310 & 0.079 & 0.162 & 0.052 & 0.080 \\
\hline $\begin{array}{l}\text { WF+ Fen +SO } \\
v s . \text { WF+SO }\end{array}$ & 0.006 & 0.016 & -0.021 & 0.145 & 0.027 & 0.889 \\
\hline
\end{tabular}

\section{WF; Wheat Flour

RF; Rice Flour

\section{Quality of separation:}

Good bread must have top bottom layers completely separated from each other un completely separated loaves are unacceptable and evaluated by lower score. This character is evaluated as the most important character. Table (24) presented the orthogonal comparisons between different levels of rice flour substitution to wheat flour reflected on quality of separation for the studied flour blends. Misr2 wheat flour replaced by $10 \%$ rice flour, recorded better
Fen; Fenugreek Flour Soy; Soybean flour quality of separation than blends with $20 \%$ rice flour. Meanwhile, the wheat cultivar blends with $20 \%$ replacement by rice flour, surpassed blend with $30 \%$ rice flour in quality of separation. Giza 171 wheat flour with $10 \%$ rice flour replacement, showed better quality of separation than blends with $20 \%$ rice flour. Meanwhile, raising the level of rice flour in blends to $30 \%$, decreased the score of separation quality. Similar results to those of Giza171 were recorded for Gimmeza11 wheat cultivar blends.

Table 24: Orthogonal comparisons between different levels of rice flour substitution to wheat flour reflected on Quality of separation of the flour blend.

\begin{tabular}{|l|c|c|c|c|c|c|}
\hline \multirow{2}{*}{ Comparisons } & \multicolumn{5}{|c|}{ Wheat cultivar } & \multicolumn{2}{c|}{ Gimmeza11 } \\
\cline { 2 - 7 } & \multicolumn{2}{|c|}{ Misr2 } & \multicolumn{2}{|c|}{ Giza171 } & Significance \\
\cline { 2 - 7 } & Effect & Significance & Effect & Significance & Effect & Signa \\
\hline $\begin{array}{l}\text { WF+ 10\% RF v.s } \\
\text { WF+20\% RF }\end{array}$ & 0.333 & 0.134 & -0.444 & 0.232 & -0.056 & 0.048 \\
\hline $\begin{array}{l}\text { WF+ 20\% RF v.s } \\
\text { WF+30\%RF }\end{array}$ & -1.389 & 0.000 & 0.389 & 0.295 & 0.611 & 0.019 \\
\hline
\end{tabular}

WF; Wheat Flour RF; Rice Flour

Sorghum flour substitution to wheat flour at different levels affected loaves layers separation differently (Table 25). Misr2 wheat replaced by $10 \%$ sorghum flour, showed insignificantly better layer separation than blends with $20 \%$ sorghum flour. Also, $20 \%$ sorghum flour replacement gained significantly better quality of separation than blends with $30 \%$ sorghum flour. Giza171 wheat flour substituted by $20 \%$ sorghum flour showed significantly better
Fen; Fenugreek Flour Soy; Soybean flour quality of separation than $10 \%$ sorghum blends. Also, the former blends significantly surpassed those with $30 \%$ sorghum flour in quality of separation. Gimmeza11 wheat blends with $10 \%$ sorghum flour significantly expressed better quality of separation than blends with $20 \%$ sorghum flour. While, increasing the level of sorghum flour to $30 \%$, substantially improved quality of separation than blend with $20 \%$ sorghum.

Table 25: Orthogonal comparisons between different levels of sorghum flour substitution to wheat flour reflected on Quality of separation of the flour blend

\begin{tabular}{|c|c|c|c|c|c|c|}
\hline \multirow{3}{*}{ Comparisons } & \multicolumn{6}{|c|}{ Wheat cultivar } \\
\hline & \multicolumn{2}{|r|}{ Misr2 } & \multicolumn{2}{|c|}{ Giza171 } & \multicolumn{2}{|c|}{ Gimmeza11 } \\
\hline & Effect & Significance & Effect & Significance & Effect & Significance \\
\hline $\begin{array}{l}\mathrm{WF}+10 \% \mathrm{SF} v \cdot s \\
\mathrm{WF}+20 \% \mathrm{SF}\end{array}$ & -0.222 & 0.316 & 0.889 & 0.019 & 1.000 & 0.000 \\
\hline $\begin{array}{l}\mathrm{WF}+20 \% \mathrm{SF} v \cdot s \\
\mathrm{WF}+30 \% \mathrm{SF}\end{array}$ & -0.889 & 0.000 & -1.889 & 0.000 & 0.833 & 0.002 \\
\hline
\end{tabular}

WF; Wheat Flour

RF; Rice Flour

Fen; Fenugreek Flour

Soy; Soybean flour 
Comparisons regarding the role of barley flour separation level effect on loaves quality of separation were shown in (Table 26). Barley flour replaced at $10 \%$ level to Misr2 wheat flour, gave significantly better layer separation than blends with $20 \%$ barley flour. While, blends with $30 \%$ barley flour, significantly expressed, better layers separation than blends with $20 \%$ barley flour. Giza171 wheat flour, replaced by $20 \%$ barley flour showed insignificantly better quality of separation. While, $30 \%$ level of barley flour replacement, significantly recorded better layers separation. Gimmeza11 wheat flour blends expressed similar results to those of Giza171 wheat flour.

Table26: Orthogonal comparisons between different levels of barley flour substitution to wheat flour reflected on Quality of separation of the flour blend

\begin{tabular}{|l|c|c|c|c|c|c|}
\hline \multirow{2}{*}{ Comparisons } & \multicolumn{6}{|c|}{ Wheat cultivar } \\
\cline { 2 - 7 } & \multicolumn{2}{|c|}{ Misr2 } & \multicolumn{2}{c|}{ Giza171 } & \multicolumn{2}{|c|}{ Gimmeza11 } \\
\cline { 2 - 7 } & Effect & Significance & Effect & Significance & Effect & Significance \\
\hline $\begin{array}{l}\text { WF+ 10\% BF v.s } \\
\text { WF+20\% BF }\end{array}$ & -0.833 & 0.000 & 0.667 & 0.075 & 0.500 & 0.054 \\
\hline $\begin{array}{l}\text { WF+ 20\%BF v.s } \\
\text { WF+30\%BF }\end{array}$ & 0.444 & 0.047 & 0.056 & 0.023 & 0.833 & 0.002 \\
\hline
\end{tabular}

WF; Wheat Flour

RF; Rice Flour

Comparisons between pairs of cereal flours used for substitution, in relation to quality of layers separation were presented in (Table 27). Misr2 wheat flour substituted by rice flour in blends, insignificantly surpassed blends with sorghum flour regarding quality of separation. Also, blends with rice flour, significantly excelled blends with barley flour in leaves layers separation. Giza171 wheat flour replaced by sorghum flour, significantly ex-
Fen; Fenugreek Flour Soy; Soybean flour pressed better layers separation. In the meantime, blend with rice flour gave significantly better layers separation than blends with barley flour. Gimmeza11 wheat flour blends with sorghum flour, insignificantly gave better layers separation than blends with rice flour. While, blends of rice flour, showed insignificant superiority in quality of separation than blends with barley flour.

Table 27; Orthogonal comparison for the effect of pulse flours supplementation to wheat /local cereals flours on Quality of separation of flour blend

\begin{tabular}{|l|c|c|c|c|c|c|}
\hline \multirow{3}{*}{ Comparisons } & \multicolumn{3}{|c|}{ Wheat cultivar } \\
\cline { 2 - 8 } & \multicolumn{2}{|c|}{ Misr2 } & \multicolumn{2}{|c|}{ Giza171 } & \multicolumn{3}{c|}{ Gimmeza11 } \\
\cline { 2 - 8 } & Effect & Significance & Effect & Significance & Effect & Significance \\
\hline WF+ RFv.s WF+SF & 0.074 & 0.341 & -1.259 & 0.000 & 0.111 & 0.574 \\
\hline WF +RF v.s WF+ BF & 0.500 & 0.000 & -0.815 & 0.000 & -0.111 & 0.574 \\
\hline
\end{tabular}

WF; Wheat Flour RF; Rice Flour

The role of pulse flours in modifying quality of loaves layers separation as orthogonal comparisons were illustrated in (Table 28). In the three studied wheat cultivars, fenugreek flour in various cereals blends expressed lower quality of separation. This effect was only significant $(\mathrm{P} \geq 0.00)$ for Giza171wheat flour blends. The role of soybean flour when added to fenugreek flour in blends in a comparison to blends that contained fenugreek flour only,

Fen; Fenugreek Flour Soy; Soybean flour

showed that, the presence of soybean flour in blends of all studied wheat cultivars lowered the score given to quality of separation. That decrease was only significant for blends of Giza171 wheat cultivar. The separate role of soybean in blends in comparison to both of fenugreek and soybean in blends, showed that soybean flour alone in blends insignificantly improved the quality of separation.

Table 28: Orthogonal comparison for the effect of pulse flours supplementation to wheat /local cereals flours on Quality of separation of flour blend

\begin{tabular}{|c|c|c|c|c|c|c|}
\hline \multirow{3}{*}{ Comparisons } & \multicolumn{6}{|c|}{ Wheat cultivar } \\
\hline & \multicolumn{2}{|c|}{ Misr2 } & \multicolumn{2}{|c|}{ Giza171 } & \multicolumn{2}{|c|}{ Gimmeza11 } \\
\hline & Effect & Significance & Effect & Significance & Effect & Significance \\
\hline $\begin{array}{l}\mathrm{WF}+(\mathrm{RF}, \mathrm{SF}, \mathrm{BF})+\mathrm{Fen} \\
v s . \mathrm{WF}+(\mathrm{RF}, \mathrm{SF}, \mathrm{BF})+\mathrm{SO}\end{array}$ & 0.117 & 0.940 & 0.767 & 0.000 & 0.183 & 0.193 \\
\hline $\mathrm{WF}+\mathrm{Fen}+\mathrm{SO}$ vs. $\mathrm{WF}+\mathrm{Fen}$ & 0.042 & 0.684 & 0.230 & 0.009 & 0.103 & 0.088 \\
\hline $\mathrm{WF}+\mathrm{Fen}+\mathrm{SO}$ vs. $\mathrm{WF}+\mathrm{SO}$ & 0.021 & 0.171 & 0.091 & 0.294 & 0.070 & 0.245 \\
\hline
\end{tabular}

WF; Wheat Flour $\quad$ RF; Rice Flour $\quad$ Fen; Fenugreek Flour $\quad$ Soy; Soybean flour 


\section{Evenness of layers:}

Evenness of layers stand for uniformity of thickness for loaf's upper and lower layers. Orthogonal comparisons between different levels of rice flour substitution to wheat flour reflected on evenness of layers for the studied flour blends were presented in Table 29. Blends of Misr2 wheat flour with $20 \%$ rice flour replacement showed significantly uniform loaf layers thickness compared to blends with $10 \%$ rice flour. Meanwhile, the same cultivar flour blends with
$20 \%$ rice gave loaves of significantly better evenness of layers relative to blends with $30 \%$ rice flour. Giza171 wheat flour blends that had $10 \%$ rice flour were of insignificantly different layer thickness evenness in comparison to blends with $20 \%$ rice flour. While, blends with $30 \%$ rice flour showed significant evenness of loaf's layers in comparison to blends with $20 \%$ rice flour. Gimmeza11 wheat flour blends showed similar response to what recorded with Giza171 wheat cultivar.

Table 29: Orthogonal comparisons between different levels of rice flour substitution to wheat flour reflected on evenness of layers for the studied flour blends

\begin{tabular}{|c|c|c|c|c|c|c|}
\hline \multirow{3}{*}{ Comparisons } & \multicolumn{6}{|c|}{ Wheat cultivar } \\
\hline & \multicolumn{2}{|c|}{ Misr2 } & \multicolumn{2}{|c|}{ Giza171 } & \multicolumn{2}{|c|}{ Gimmeza11 } \\
\hline & Effect & Significance & Effect & Significance & Effect & Significance \\
\hline $\begin{array}{l}\mathrm{WF}+10 \% \mathrm{RF} v . s \\
\mathrm{WF}+20 \% \mathrm{RF}\end{array}$ & 0.667 & 0.000 & -0.278 & 0.075 & -0.500 & 0.000 \\
\hline $\begin{array}{l}\text { WF+ 20\% RF v.s } \\
\text { WF+30\%RF }\end{array}$ & -0.556 & 0.001 & 0.333 & 0.034 & 0.611 & 0.000 \\
\hline \multicolumn{7}{|c|}{ 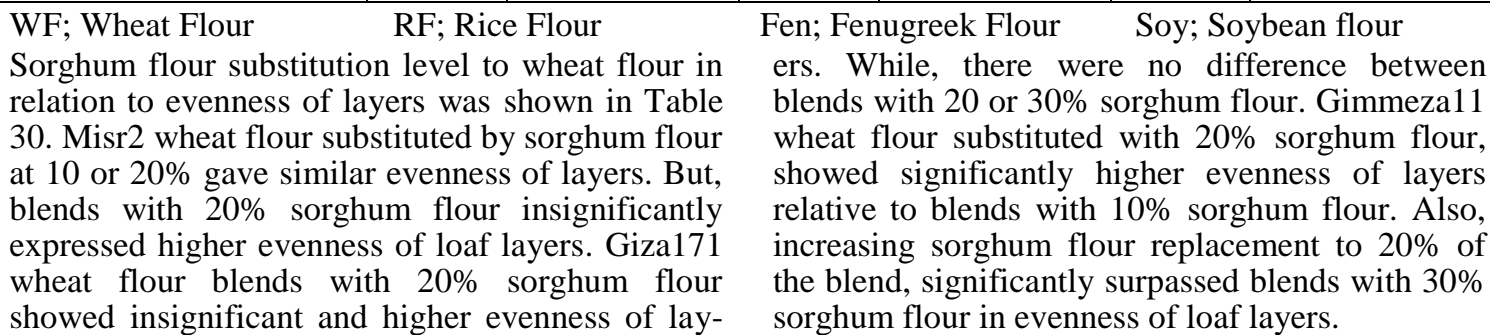 } \\
\hline
\end{tabular}

Table 30: Orthogonal comparisons between different levels of sorghum flour substitution to wheat flour reflected on evenness of layers for the studied flour blends.

\begin{tabular}{|l|c|c|c|c|c|c|}
\hline \multirow{2}{*}{ Comparisons } & \multicolumn{6}{|c|}{ Wheat cultivar } \\
\cline { 2 - 7 } & \multicolumn{2}{|c|}{ Misr2 } & \multicolumn{2}{c|}{ Giza171 } & \multicolumn{2}{c|}{ Gimmeza11 } \\
\cline { 2 - 7 } & Effect & Significance & Effect & Significance & Effect & Significance \\
\hline $\begin{array}{l}\text { WF+ 10\% SF } v . s \\
\text { WF+20\% SF }\end{array}$ & -0.000 & 0.000 & 0.111 & 0.525 & -0.611 & 0.000 \\
\hline $\begin{array}{l}\text { WF+ 20\%SF } v . s \\
\text { WF+30\%SF }\end{array}$ & -0.167 & 0.302 & -0.000 & 0.000 & -0.611 & 0.000 \\
\hline
\end{tabular}

WF; Wheat Flour RF; Rice Flour

Barley flour replacement to wheat flour reflected on evenness of loaf layers were presented in Table 31 . Misr 2 wheat flour substituted by $10 \%$ barley flour expressed insignificantly higher degree of layers evenness compared to blends with $20 \%$ barley flour. While, blends with $30 \%$ barley flour, significantly surpassed blends with $20 \%$ barley flour in evenness

Fen; Fenugreek Flour Soy; Soybean flour
of loaf layers. Giza171 wheat flour with $20 \%$ barley flour insignificantly showed better evenness of layers. While, blends with $30 \%$ barley significantly showed higher evenness of layers. Gimmeza11 wheat flour showed responses similar to those of Misr2 wheat flour blends, but the responses in evenness of layers were significant in all comparisons.

Table 31: Orthogonal comparisons between different levels of barley flour substitution to wheat flour reflected on evenness of layers for the studied flour blends.

\begin{tabular}{|l|c|c|c|c|c|c|}
\hline \multirow{2}{*}{ Comparisons } & \multicolumn{6}{|c|}{ Wheat cultivar } \\
\cline { 2 - 8 } & \multicolumn{2}{|c|}{ Misr2 } & \multicolumn{2}{c|}{ Giza171 } & \multicolumn{2}{c|}{ Gimmeza11 } \\
\cline { 2 - 8 } & Effect & Significance & Effect & Significance & Effect & Significance \\
\hline $\begin{array}{l}\text { WF+ 10\% BF } v . s \\
\text { WF+20\% BF }\end{array}$ & -0.278 & 0.088 & 0.111 & 0.525 & -0.500 & 0.000 \\
\hline $\begin{array}{l}\text { WF+ 20\%BF v.s } \\
\text { WF+30\%BF }\end{array}$ & 0.444 & 0.007 & 0.333 & 0.034 & 0.611 & 0.000 \\
\hline
\end{tabular}

WF; Wheat Flour

RF; Rice Flour

Fen; Fenugreek Flour

Soy; Soybean flour 
Comparisons between blends that included different cereals in relation to loaf's evenness of layers were presented in Table 32. Blends of Misr2 or Gimmeza11 cultivars with sorghum flour gave better evenness of layers in comparison with blends with rice flour. Also, blends of the formally stated wheat cultivars with barley flour, expressed better evenness of layers than the corresponding blends with rice flour. Giza171 wheat flour blends with rice flour, expressed better evenness of layers in comparison with blends included sorghum flour. In the meantime, blends with rice flour gave better evenness of layers in comparison of those included barley flour.

Table 32: Orthogonal comparison for the effect of pulse flours supplementation to wheat/local cereals flours on evenness of layers of flour blend

\begin{tabular}{|l|c|c|c|c|c|c|}
\hline \multirow{2}{*}{ Comparisons } & \multicolumn{5}{|c|}{ Wheat cultivar } \\
\cline { 2 - 7 } & \multicolumn{2}{|c|}{ Misr2 } & \multicolumn{2}{c|}{ Giza171 } & \multicolumn{2}{c|}{ Gimmeza11 } \\
\cline { 2 - 7 } & Effect & Significance & Effect & Significance & Effect & Significance \\
\hline $\begin{array}{l}\text { WF+ RFv.s } \\
\text { WF+SF }\end{array}$ & 0.130 & 0.166 & -0.296 & 0.001 & 0.111 & 0.130 \\
\hline $\begin{array}{l}\text { WF +RF } v . s \\
\text { WF+ BF }\end{array}$ & 0.315 & 0.001 & -0.241 & 0.009 & 0.111 & 0.130 \\
\hline
\end{tabular}

WF; Wheat Flour $\quad$ RF; Rice Flour

The role of pulse flour in modifying evenness of loaf layers were presented in Table 33. Blends of all studied wheat cultivars flour that included soybean flour, significantly and positively affected layers evenness over those included fenugreek flour. To illustrate the single role of soybean flour in modifying layers evenness, comparison was made between blend contained both of fenugreek and soybean flours versus blends that contained fenugreek flour only. Blends that contained flours of two pulses expressed less evenness of layers in comparison with blends that contained fenugreek
Fen; Fenugreek Flour

Soy; Soybean flour

flour only. Also, blend that contained flours of two pulses expressed less evenness of layers relative to blends that contained soybean flour only.

Wheat cultivar suitability for bread making is largely influenced by its genetic make-up. The variety becomes suitable for bread-making when the ability of proteins for constructing dimensional networks of gluten during kneading is greater. Environmental factors such as nitrogen fertilization, irrigation and climatic factors influence protein content. But protein quality is largely under genetic control.

Table 33: Orthogonal comparison for the effect of pulse flours supplementation to wheat /local cereals flours on Evenness of layers of flour blend

\begin{tabular}{|l|c|c|c|c|c|c|}
\hline \multirow{2}{*}{ Comparisons } & \multicolumn{4}{|c|}{ Wheat cultivar } \\
\cline { 2 - 7 } & \multicolumn{2}{|c|}{ Misr2 } & \multicolumn{2}{c|}{ Giza171 } & \multicolumn{2}{c|}{ Gimmeza11 } \\
\cline { 2 - 7 } & Effect & Significance & Effect & Significance & Effect & Significance \\
\hline $\begin{array}{l}\text { WF+ (RF, SF, BF)+Fen } \\
\text { vs. WF+(RF,SF,BF)+SO }\end{array}$ & 0.217 & 0.016 & 0.283 & 0.001 & 0.167 & 0.018 \\
\hline $\begin{array}{l}\text { WF +Fen +SO } \\
\text { vs. WF + Fen }\end{array}$ & 0.109 & 0.005 & 0.100 & 0.007 & 0.012 & 0.172 \\
\hline $\begin{array}{l}\text { WF+ Fen+ SO } \\
\text { vs. WF+SO }\end{array}$ & 0.070 & 0.067 & 0.048 & 0.181 & -0.018 & 0.386 \\
\hline
\end{tabular}

\section{WF; Wheat Flour

RF; Rice Flour

Baking potential of wheat flour is influenced by many factors, the most important of them is protein content (Johnson and Moss, 1990; Randall and Moss, 1990 and Johanson and Svensson, 1998). Grain virtuousness is related to the endosperm microstructure, whereas, hardness is suggested to influence the adhesion forces between starch granules and protein matrix (Al- Saleh and Gallent, 1985). Many studied investigating bread baking performances have addressed protein properties, with particular emphasis on gluten strength. Differences in baking quality among cultivars have

\section{Fen; Fenugreek Flour Soy; Soybean flour}

been related to differences in gluten composition, particularly to the high molecular weight glutenin subunits (Weegles et.al, 1996, Preston et.al, 1992 and Wieser and Zimmermann, 1994). However, the separation of protein fractions, which minimize the possibility to predict the baking quality in correlation with the flour characteristics (Preston et al, 1992 and Schofield, 1994). The recent results were in general agreement with previous studies (Sharma et al, 1999; Coskuner and Karababa, 2005; Majzoobi et al, 2011; Muranga et al, 2010). Rai et al., 2012, stated that during bread making, the op- 
timum level of incorporation decreased the sensory quality of bread. Sanchez et al. (2002) reported maximum of response surface for crumb-grain score and bread score which revealed that optimum bread can be prepared from $72.2 \%$ corn starch, $17.2 \%$ rice flour and $8.6 \%$ cassava starch. Similar finding to the recent results were reported by Patel et al. (1996) who stated that the quality of bread prepared using composite flours dad decreased. Shalini and Lakshmi (2005) reported that the bread incorporated with $30 \%$ wheat bran, $20 \%$ finger millet flour, $10 \%$ ginger, $10 \%$ garlic and $3 \%$ mixed spices was well accepted.

Lópezet al. (2004), evaluated several formulations aiming to find a flour mixture to replace wheat flour in the production of free-gluten white bread from rice flour, corn and cassava starch. They found that rice flour bread presented the best parameters, being preferred by the sensory evaluation panel, followed by corn starch bread and cassava starch bread. Breads prepared with rice flour resulted in a softer product, presenting a better consistency with small alveoli homogeneously distributed. As far as crumb texture was concerned, corn starch bread presented larger alveoli. Also, production parameters were established based on these results and a mixture of flours, composed by $45 \%$ rice flour, $35 \%$ corn starch and $20 \%$ cassava starch presented good results originating bread with crumb formed by uniform and well distributed cells, and pleasant flavor and appearance. Phimolsiripol et al. (2012), investigated the principal effect of adding rice bran to glutenfree (GF) bread (based on refined rice flour and a dough system of protein/emulsifier/hydrocolloid) and to adapt its recipe parameters - amount of egg albumen, emulsifier and hydroxypropyl methylcellulose. They showed that, the increased dietary fiber enhanced the nutritional profile of the GF breads, which were preferred over the control bread by a sensory panel. Rai et al. (2012), determined proximate composition and pasting properties of raw materials, bread making quality and sensory qualities of breads produced from varying substitutions of rice flour and maize meal with wheat flour. They indicated that, the sensory evaluation revealed that $25 \%$ replacement of wheat flour was found to be more acceptable than control sample. Khoshgozaran-Abras et al. (2014), indicated that, it was feasible to incorporate brown rice (BR) flour for baking Barbary flat bread; However, the threshold of BR flour addition should be $\leq 5 \%$. This is simply because, dough made from blend flour fortified with $5 \%$ BR flour, due to rheological evaluation, was strong and baked flat bread was highly ranked acceptable by panelists.

Carson et al. (2000), tested bread made from a $50 \%$ sorghum-based composite flour by six trained panelists. A descriptive test was used to identify the characteristics of aroma, crumb flavor, top crust flavor and texture of the bread by comparison with a commercial rye bread. They found the slightly higher score for sourness and astringency in the crust in the sorghum composite bread than in the rye bread should be noted, because it indicates an attribute generally associated with sorghum flour. The acceptance test indicated that the $50 \%$ sorghum composite bread was well received by most of the panelists, having an average rating of 6.9 on the 9-point hedonic scale, compared to an average of 6.1 for bread with up to $30 \%$ sorghum flour in the study. These results indicated that, up to $50 \%$ sorghum flour was acceptable in taste, and further testing of this product is in progress. Amir et al. (2015), investigated Seven blends prepared by homogenously mixing maize and sorghum flours with wheat flour in the percentage proportions: 0:100, 10:90, 20:80, 30:70, 15:15:70 (MF: WWF, SF: WWF and MF: SF: WWF). They found that, the addition of sorghum, maize and a combination of these whole flours have highly significant effect $(p<0.01)$ on the sensory characteristics of cookies. Sibanda et al. (2015) studied the effect of partial substitution of wheat flour with white grain sorghum flour on the rheological properties and bread making quality of the composites. Composite flours containing $10 \%, 20 \%$ and $30 \%$ sorghum were analyzed. The sensory analysis of the baked product indicated that, there was no significant difference in the taste, flavor and texture of the composite bread. The incorporation of sorghum at $10 \%$ produces bread of similar quality to wheat flour. Although increasing wheat replacement negatively affects the physicochemical and rheological properties, the sensory quality of the bread remains acceptable.

Niffenegger (1964) their resulted showed that, the starch and proteins of barley and wheat flour behave differently. Appearance and flavor are usually affected by the addition of barley flour. Dhingar and Jood (2002), studied the Supplementation of soy (full fat and defatted) and barley flours to wheat flour at 5,10, 15 and $20 \%$ levels were studied. All the blends at $20 \%$ levels were found nutritionally superior, but breads prepared from them found organoleptically unacceptable. However, addition of $15 \%$ barley flour, $10 \%$ full fat soy flour, $10 \%$ defatted soy flour, $15 \%$ full fat soy flour+ barley flour and $15 \%$ defatted soy flour+ barley flour to wheat flour produce a product of acceptable quality. Dhingra and Jood (2004) concluded that, the substitution of wheat flour with soybean and barley flour up to an amount equivalent to $10 \%$ of full-fat and defatted soyflour, $15 \%$ for barley flour, full-fat soy + barley flour and defatted soy + barley flour produced acceptable bread loaves with good organoleptic characteristics. Ereifej et al. (2006), reached that, when increasing barley flour content beyond these limits, the resulting bread loaves are found to be harder, darker in color, and non-uniformly-shaped; therefore, less acceptable bread. Sullivan et al. (2010) from taste panel results indicated that, the addition of barley flour to a wheat flour formulation does not have a significant effect on bread acceptability up to $50 \%$ barley flour addition. The results would indicate that, there is potential for a bread product containing up to $50 \%$ barley flour.Maiya et al. (2013), from Sensory analysis showed that, the use of barely flour above $30 \%$ 
brought about adverse effect on the quality of parotta. Reddy et al. (2013), evaluated the milling quality characteristics of different cereals and organoleptic evaluation of traditional food products. They found that, barley comes under cereal grains and is staple food in most countries of the Middle East. It is having almost equal importance to wheat. However, it is less palatable than wheat. Flour made from barley can be used as substitute for wheat flour. Further research is needed to improve the palatability of barley and to formulate more barley recipes. Mariotti et al. (2014) showed that, the barley sourdoughs investigated could be used to obtain barley bread with enhanced nutritional value. Furthermore, no significant differences were seen in the degree of liking among the three breads after baking and during shelf-life, thus confirming the possibility for successful exploitation of barley flour in the baking industry.

\section{Bread stalling:}

Baked loaves for each flour blend were cooled, bagged in polyethylene bags and stored at room temperature. Bread stalling was determined by texture testing procedure after one, three and five days of storage. Bread stalling refers to all the changes which occur in bread after baking and has been defined as "a term which indicates decreasing consumer acceptance of bread by changes in the crumb other than those resulting from action of spoilage organisms". Hardness stand for loss of elasticity and increase in firmness, expressed as load per area unit $\left(\mathrm{g} . \mathrm{cm}^{-2}\right)$.

Analysis of variance for data of hardness were carried out for each tested wheat cultivar as split-plot with days of measurements as main (three days) and blends (31 flour blends) as sub plots. Analysis over cultivars was carried out to infer the interactions among cultivar and other factors (blends and days). Table 34 illustrated the mean squares of hardness data. Wheat cultivars were significantly ( $\mathrm{p} \geq 0.01)$ different. Also, reading among days and the interaction between cultivars and day of reading was significant $(p \geq 0.01)$. Flour blends showed significant differences regarding the recorded values of hardness. Interactions between cultivar $\times$ blend, day $\times$ blend and cultivar $\times$ day $\times$ blend were significant $(\mathrm{p} \geq 0.01)$.

Table 34: Mean squares of hardness $\left({\mathrm{g} . \mathrm{cm}^{-2}}^{-2}\right)$ as an indicator of stalling for days of measurement and flour blends combined over wheat cultivars.

\begin{tabular}{|l|l|l|}
\hline S.O.V. & d.f. & M.S \\
\hline Wheat cultivar (A) & 2 & $65057884.4^{* *}$ \\
\hline Rep/cultivar & 6 & 301.6 \\
\hline Day of measurement (B) & 2 & $17687908.6^{* *}$ \\
\hline A $\times$ B & 4 & $7861976.2^{* *}$ \\
\hline Error & 12 & 16802.7 \\
\hline Flour blends (C) & 30 & $1452665.2^{* *}$ \\
\hline A $\times$ C & 60 & $1261552.5^{* *}$ \\
\hline $\mathrm{B} \times \mathrm{C}$ & 60 & $587776.7^{* *}$ \\
\hline $\mathrm{A} \times \mathrm{B} \times \mathrm{C}$ & 120 & $657092.9^{* *}$ \\
\hline Error & 540 & 9718.8 \\
\hline
\end{tabular}

Table 35 illustrated the interaction between cultivars and day of measurement for hardness reading. Power required for crumb deformation of bread slices were significantly ascending from day one (after baking) to day three (maximum expected storage) (342.6, 407.7 and 807.6 g.cm ${ }^{-2}$ for days one, two and three respectively). Among wheat cultivars, Gimmeza11 significantly maintained low firmness and high elasticity (low hardness) (198.1 g.cm ${ }^{-2}$ ). While, Misr2 cultivar enjoyed maximum hardness $\left(1074.6 \mathrm{~g} . \mathrm{cm}^{-2}\right)$. The least hardness value was presented by Gimmeza11 cultivar at day one of storage $\left(91.11 \mathrm{~g} . \mathrm{cm}^{-2}\right)$. Whereas, maximum significant hardness was recorded by Misr2 cultivar at day three of storage $\left(1728.1 \mathrm{~g} . \mathrm{cm}^{2}\right)$.

\begin{tabular}{|l|l|l|l|l|}
\hline \multicolumn{1}{|c|}{ Day Cultivars } & Day one & Day two & Day three & Means \\
\hline Misr2 & 790.2 & 705.6 & 1728.1 & $1074.6^{\mathrm{c}}$ \\
\hline Giza171 & 146.6 & 238.6 & 470.2 & $285.1^{\mathrm{b}}$ \\
\hline Gimmeza11 & 91.1 & 278.9 & 224.4 & $198.1^{\mathrm{a}}$ \\
\hline Means & $342.6^{\mathrm{a}}$ & $407.7^{\mathrm{b}}$ & $807.6^{\mathrm{c}}$ & \\
\hline
\end{tabular}

Table 36 illustrated the hardness values as affected by blend $x$ wheat cultivar interaction. Bread hardness significantly decreased when rice flour replaced wheat flour at $10 \%$ level (759.3 vs. 426.6 for full wheat flour versus wheat $+10 \%$ rice flour blend, respectively), indicating higher fresh ability due to rice flour inclusion at $10 \%$ level. Raising the level of rice flour substitution to 20 or $30 \%$ of wheat flour maintained bread fresh ability (395.8 and $433.1 \mathrm{~g} . \mathrm{cm}^{-2}$ for blends of 20 and $30 \%$ rice flour, respectively), inclusion of fenugreek flour in blends of wheat + rice flour reduced bread fresh ability through raising the level of hardness (927.6,

765.3 and 753.7 g.cm ${ }^{-2}$ for blends with fenugreek flour at $10 \%, 20 \%$ and $30 \%$ rice flour substitution levels, respectively). Soybean flour inclusion to blends produced bread of intermediate hardness values between blends with fenugreek flour and full wheat flour $(605.5,633.1$ and $771.5 \mathrm{~g} . \mathrm{cm}-2$ for blends with soybean flour at 10, 20 and $30 \%$ rice flour substitution). Blends substituted with sorghum flour produced less stalled bread (higher hardness) than the corresponding levels of substitution for rice flour. The role of fenugreek flour in decreasing the stall ability of bread was also continued along with lesser effect by soybean flour. 
The best fresh ability score was those recorded for barley flour blends (265.4, 431.1 blends with 10, 20 and $30 \%$ barley flour). $5 \%$ fenugreek flour inclusion with barley at $10 \%$ level of replacement, improved fresh ability of bread, whereas, the best stalled bread resulted with blend of wheat flour $+10 \%$ barley flour $+5 \%$ soybean flour $\left(86.43 \mathrm{~g} . \mathrm{cm}^{-2}\right)$. Raising the level of barley flour to $20 \%$ gave bread of hardness like that of the blend included $10 \%$ rice flour (431.1 and 426.5 for the former and the latter, respectively). The level of hardness was proportional to the level of barley flour substitution in the blend. Misr2 cultivar expressed the highest figures of hardness irrespective of the flour blend, whereas, Gimmeza11 enjoyed the highest level of bread freshability.

Bread stalling is an extremely complex phenomenon. Flour, the primary constituent of bread, contains in addition to carbohydrates, proteins and lipids, a whole series of transitional compounds. The various

Table 36: Hardness over storage days as affected by

\begin{tabular}{|c|c|c|c|c|c|}
\hline \multirow{2}{*}{\multicolumn{2}{|c|}{ Treatments }} & \multicolumn{3}{|c|}{ Cultivars } & \multirow{2}{*}{ Means } \\
\hline & & Misr2 & Giza171 & Gimmeza11 & \\
\hline 1 & WF $100 \%$ & 1907.222 & 275.956 & 94.767 & 759.3 \\
\hline 2 & $\mathrm{WF}+10 \% \mathrm{RF}$ & 929.000 & 287.089 & 63.656 & 426.5 \\
\hline 3 & $\mathrm{WF}+10 \% \mathrm{RF}+5 \% \mathrm{Fen}$ & 1938.000 & 788.244 & 56.567 & 927.6 \\
\hline 4 & $\mathrm{WF}+10 \% \mathrm{RF}+5 \%$ So & 1717.222 & 37.922 & 61.411 & 605.5 \\
\hline 5 & $\mathrm{WF}+20 \% \mathrm{RF}$ & 848.798 & 214.358 & 124.469 & 395.8 \\
\hline 6 & $\mathrm{WF}+20 \% \mathrm{RF}+5 \% \mathrm{Fen}$ & 1603.494 & 466.100 & 226.406 & 765.3 \\
\hline 7 & $\mathrm{WF}+20 \% \mathrm{RF}+5 \%$ So & 1603.494 & 202.540 & 67.842 & 633.1 \\
\hline 8 & $\mathrm{WF}+30 \% \mathrm{RF}$ & 937.667 & 167.456 & 195.056 & 433.3 \\
\hline 9 & $\mathrm{WF}+30 \% \mathrm{RF}+5 \% \mathrm{Fen}$ & 1579.633 & 244.467 & 437.033 & 753.7 \\
\hline 10 & $\mathrm{WF}+30 \% \mathrm{RF}+5 \%$ So & 1823.889 & 403.489 & 87.233 & 771.5 \\
\hline 11 & $\mathrm{WF}+10 \% \mathrm{SF}$ & 1160.667 & 331.667 & 158.744 & 550.359 \\
\hline 12 & $\mathrm{WF}+10 \% \mathrm{SF}+5 \% \mathrm{Fen}$ & 836.511 & 762.889 & 218.022 & 605.807 \\
\hline 13 & $\mathrm{WF}+10 \% \mathrm{Sf}+5 \%$ So & 1605.889 & 347.306 & 127.678 & 693.624 \\
\hline 14 & $\mathrm{WF}+20 \% \mathrm{SF}$ & 1029.243 & 259.410 & 97.287 & 461.980 \\
\hline 15 & $\mathrm{WF}+20 \% \mathrm{SF}+5 \% \mathrm{Fen}$ & 1110.794 & 601.990 & 426.179 & 712.988 \\
\hline 16 & $\mathrm{WF}+20 \% \mathrm{SF}+5 \%$ So & 1708.312 & 232.278 & 98.039 & 679.543 \\
\hline 17 & $\mathrm{WF}+30 \% \mathrm{SF}$ & 1095.778 & 239.333 & 56.400 & 463.837 \\
\hline 18 & $\mathrm{WF}+30 \% \mathrm{SF}+5 \% \mathrm{Fen}$ & 1500.444 & 560.411 & 711.833 & 924.230 \\
\hline 19 & $\mathrm{WF}+30 \% \mathrm{SF}+5 \%$ So & 2146.444 & 166.122 & 88.223 & 800.263 \\
\hline 20 & $\mathrm{WF}+10 \% \mathrm{BF}$ & 468.167 & 223.967 & 104.300 & 265.4 \\
\hline 21 & $\mathrm{WF}+10 \% \mathrm{BF}+5 \% \mathrm{Fen}$ & 379.411 & 199.867 & 128.944 & 236.0 \\
\hline 22 & $\mathrm{WF}+10 \% \mathrm{BF}+5 \%$ So & 105.622 & 71.444 & 82.233 & 86.4 \\
\hline 23 & $\mathrm{WF}+20 \% \mathrm{BF}$ & 959.716 & 243.102 & 90.737 & 431.1 \\
\hline 24 & $\mathrm{WF}+20 \% \mathrm{BF}+5 \% \mathrm{Fen}$ & 568.817 & 199.747 & 221.200 & 329.9 \\
\hline 25 & $\mathrm{WF}+20 \% \mathrm{BF}+5 \%$ So & 175.180 & 93.541 & 269.971 & 179.5 \\
\hline 26 & $\mathrm{WF}+30 \% \mathrm{BF}$ & 1651.778 & 311.078 & 96.083 & 686.3 \\
\hline 27 & $\mathrm{WF}+30 \% \mathrm{BF}+5 \% \mathrm{Fen}$ & 871.500 & 142.244 & 354.989 & 456.2 \\
\hline 28 & $\mathrm{WF}+30 \% \mathrm{BF}+5 \%$ So & 281.200 & 134.756 & 506.490 & 307.4 \\
\hline 29 & $\mathrm{WF}+5 \% \mathrm{Fen}$ & 322.756 & 160.122 & 614.814 & 365.8 \\
\hline 30 & $\mathrm{WF}+5 \%$ So & 130.467 & 188.056 & 98.844 & 139.1 \\
\hline 31 & $\mathrm{WF}+5 \% \mathrm{Fen}+5 \%$ So & 291.967 & 283.333 & 178.357 & 251.219 \\
\hline $\mathrm{Me}$ & & 1074.669 & 285.170 & 198.187 & \\
\hline
\end{tabular}

Our recent results coincide with the finding of Tsai et al. (2012) that bread containing rice flour had slower rate of firming as compared to the control. Axford et al. (1968), showed that loaf specific volume is a major factor in determining both the components present in flour eventually become the constituents of bread play an important role in bread stalling. The swelling or gelatinization properties of starch are another important parameter. The starch granule contains both amorphous and crystalline regions. During the bread baking process, gelatinization of the stare takes place during the oven stage. Howevlimited amount of water that is present. It has been shown that the rate at which crystallinity develops in concentrated starch gels is like the rate of increase in bread firmness. Amylose retrogradation or a change in the amylose fraction of the starch is important during the first day of storage. This retrogradation occurs during the oven stage. Also, the effect of amylose fraction of starch on bread stalling diminishes as the flour protein content increases. Moisture redistribution which occur between components during bread storage is also important, since, moisture transfer from starch to the gluten in the crumb or vas verse. er, the extent of gelatinization is limited due to the

by flour blends $x$ wheat cultivar interaction 
examined the effect of $5,10,15,20,25$ and $30 \%$ compression depths on the sensitivity of the data and the characteristics of the Instron curve. They resulted that as the bread crumb aged, the amount of force required to compress the crumb increased. The greatest increase in force over the seven-day storage period was between days 1 and 4 after baking. The crumb firmness also increased as the degree of compression increased. Some variability in the data is desirable since it indicates sensitivity to changes in crumb firmness either due to staling or formulation. Sidhu et al. (1997), showed that, the amount of soluble starch and amylose contents also decreased significantly as the bread aged during storage. Despite their limitation, sensory analysis parameters were found to follow the staling of white as well as extra bran Arabic bread more closely than any other single method. Instron Puncture force measurements correlated well with other chemical methods and sensory analysis parameters in white Arabic bread, but did not provide significant correlations for extra bran Arabic bread. Gray and Bemiller (2003), reached a conclusion that, bread staling is a complex phenomenon in which multiple mechanisms operate. Polymer crystallizations with the formation of super molecular structures are certainly involved. The most plausible hypothesis is that, retrogradation of amylopectin occurs, and because water molecules are incorporated into the crystallites, the distribution of water is shifted from gluten to starch/amylopectin, thereby changing the nature of the gluten network. The role of additives may be to change the nature of starch protein molecules, to function as plasticizers, and/or to retard the redistribution of water between components. Nothing more definite can be concluded at this time.Różyło and Laskowski (2011),evaluated the predictive power of flour and dough alveograph properties in simultaneous determination of bread loaf volume and crumb texture. They used ten Polish spring wheat cultivars. They showed that, from the experimental tests indicated that among the variables, the flour protein content, the Zeleny sedimentation index, the flour falling number, and dough strength were the main factors affecting the textural properties of the breadcrumb alone and with the bread loaf volume. The results showed that a combination of several flour and dough alveograph properties could predict bread quality.Amjid et al. (2013), demonstrated that, the component interactions are important for determining the rheological behaviors of gluten and flour doughs. For HMW polymers such as gluten, large deformation extensional rheological properties are more sensitive to changes in polymer entanglements and branching than small deformation dynamic shear properties, based on sound polymer physics principles and experimental data. Insoluble HMW glutenin have been shown to be best related to variations in baking quality, and to the presence of long relaxation times. Strain hardening, which has been shown to be a sensitive indicator of entanglements and long- chain branching in HMW polymers, is seen in large extensional deformation of doughs and glutens, and is well related to bubble wall stability, long relaxation times and to variations in baking performance amongst different wheat varieties .Fadda et al. (2014), confirmed the central role of amylopectin retrogradation and water redistribution within the different polymers in determining bread staling, but highlighted also the importance of other flour constituents, such as proteins and non-starch polysaccharides. Data obtained with thermal, spectroscopy, nuclear magnetic resonance, X-ray crystallography, and colorimetry analysis have pointed out the need to encourage the use of one or more of these techniques in order to better understand the mechanisms of staling. Results so far, obtained have provided new insight on bread staling, but the phenomenon has not been fully elucidated so far. Popa et al. (2014), studied the correlation between protein content, the wet gluten content and the gluten index of flour and some characteristics of bread, such as volume and the ratio height/ diameter (H/ D). They showed that, the best predictor for the bread quality parameters, i.e., volume and H/ D ratio, is the gluten fraction of the gluten index parameter which remains on the sieve (highly significant positive correlation $\mathrm{r}=0.79 * * *$, respectively $\mathrm{r}=0.73 * * *)$. Gluten index parameter correlated insignificantly with bread volume $(r=0.18)$ and significantly with the height/ diameter ratio $(0.51 *)$. In conclusion, the parameter gluten index is not relevant for the packing qualities of flour. Quality parameters could be better predicted by remaining fraction of gluten on the sieve.Nigam and Nambiar (2015), reviewed the published literature in the following; (1) bread-making mechanism may alter the protein structure, (2) the addition of different types of fibers may affect nutritional values, antioxidant status, rheological properties, and sensory attributes of baked products, (3) baking may influence added phenolic antioxidants in free forms or as components of added ingredients, (4) the increased fiber and the lower carbohydrate content of composite breads have several health benefits, as it will aid in the digestion of the bread in the colon and reduce constipation often associated with bread produced from refines wheat flour; According to well documented studies, it is now accepted that dietary fiber plays a significant role in the prevention of several diseases such as cardiovascular diseases.

\section{REFERENCE}

Axford, D.W.E., K.H. Colwell, S.J. Cornford and G.A.H. Elton (1968).Effect of loaf specific volume on the rate and extent of staling in bread.J. of Science of Food and Agriculture. Article

Alsaleh, A. D.J. Gallent, 1985. Rheological and ultrastuctural studies of wheat kernel behaviour under compression as a function of 
water content. Food Microstruct.,4, 199211.

Abdel-Kader, Z.M. (2000). Enrichment of Egyptian 'Balady' bread.Part 1. Baking studies, physical and sensory evaluation of enrichment with decorticated cracked broad beans flour (Vicia faba L.). Nahrung 44 Nr. 6, S. 418-421.

Amjid, M.R., A.Shehzad, S. Hussain, M.A. Shabbir, M.R. Khan and M. Shoaib (2013).A comprehensive review on wheat flour dough rheology. Pak. J. Food Sci., 23(2): 105-123.

Amir, B., G. Mueen-ud-din, M. Abrar, S. Mahmood, M. Nadeem and A. Mehmood (2015). Chemical composition, rheological properties and cookies making ability of composite flours from maize, sorghum and wheat. Journal of Agroalimentary Processes and Technologies, 21(1), 28-35.

Baker, A.E., C.E. Walker and K. Kemp (1988).An optimum compression depth for measuring bread crumb firmness. Cereal Chemistry, 65(4): 302- 307.

Butt, M.S., J. Iqbal, A. Naz, H.A.R. Suleria1, M.M.N. Qayyum, Faiza Saleem and M.A. Jahangir (2011).Effect of Flour Blending on Bread Characteristics. Internet Journal of Food Safety, 13: 142-149

Carson, L., C. Setser and X.S. Sun (2000).Sensory characteristics of sorghum composite bread. International Journal of Food Science and Technology, 35, 465-471.

Coskuner Y, E, Karababa (2005). Studies on the quality of Turkish flat breads based on blends of triticale and wheat flour. Int $\mathbf{J}$. Food Sci Technol 40(5):469-479

Dhingar, S. and S. Jood (2002).Physico-chemical and nutritional properties of cereal- pulse blends for bread making.Nutrition and Health, 16:183-194.

Dhingra S. and S. Jood (2004).Effect of flour blending on functional, baking and organoleptic characteristics of bread. International Journal of Food Science and Technology, 39:213-222.

Ereifej, K.I., M.A. Al-Mahasneh and T.M. Rababah (2006).Effect of barley flour on quality of balady bread. International Journal of Food Properties, 9: 39-49.

Eissa, H.A., A.S. Hussein and B.E. Mostafa (2007). Rheological properties and quality evaluation of Egyptian balady bread and biscuits supplemented with flours of ungerminated and germinated legume seeds or mushroom. Polish Journal of Food and Nutrition Science, 57 (4): 487-496.
Fadda, C., A.M. Sanguinetti, A. Del Caro, C. Collar and A. Piga (2014).Bread Staling: Updating the View. Comprehensive Reviews in Food Science and Food Safety, 13: 473492.

Gray, J.A. and J.N. Bemiller (2003).Bread staling: Molecular bass and control. Comprehensive Reviews in Food Science and Food Safety, 2: 1-11.

Hooda, S. and S. Jood (2005).Effect of fenugreek flour blending on physical, organoleptic and chemical characteristics of wheat bread. Nutrition \& Food Science, 35 (4): 229-242.

Hussein, A.M.S., M.M. Kamil, Nefisa A. Hegazy, S.A.H. Abo El-Nor (2013). Effect of Wheat Flour Supplemented with Barely and/or Corn Flour on Balady Bread Quality. Pol. J. Food Nutr. Sci., 63(1): 11-18.

Islam, M.Z., M. Shams-Ud-Din and M.A. Haque (2011).Studies on the effect of brown rice and maize flour on the quality of bread. Bangladesh Agril. Univ. 9(2): 297-304.

Khoshgozaran-Abras, S., M. H. Azizi, N. Bagheripoor-Fallah and A. Khodamoradi (2014).Effect of brown rice flour fortification on the quality of wheat-based dough and flat bread. J. Food Sci. Technol., 51(10): 2821-2826.

Kasaye, A.T. and Y.K. Jha (2015).Evaluation of composite blends of fermented fenugreek and wheat flour to assess its suitability for bread and biscuit.International Journal of Nutrition and Food Science. 4(1): 29-35.

López, A.C.B., A.J.G. Pereira and R.G. Junqueira (2004).Flour mixture of rice flour, corn and cassava starch in the production of glutenfree white bread. Brazilian Arcgives of Biology and Technology, 47(1): 63-70.

Lin, S.Y., H.H. Chen, S. Lu and P.C. Wang (2012). Effects of blendings of wheat flour with barely flour on dough and steamed bread properties. Journal of Texture Studies 43:438- 444.

Muranga FI. M. Mutambuka, F. Nabugoomu M. Lindhauer (2010). Optimisation of raw tooke flour, vital gluten and water absorption in tooke/wheat composite bread: effect of raw tooke flour and vital gluten on wheat flour physicochemical and dough rheological properties (Part I). Afr J Food Sci 4(5):223-230

Majzoobi M, FS. Ghavi A. Farahnaky J. Jamalian G. Mesbahi (2011). Effect of tomato pomace powder on the physicochemical properties of flat bread (Barbari bread). J Food Process Preserv 35(2):247-256

Mohammed, I., A.R. Ahmed, B. Senge (2012). Dough rheology and bread quality of 
wheat-chickpea flour blends. Industrial Crops and Products 36:196-202.

Maiya, G.K., B.G. Shwetha and D. Indrani.(2013). Effect of barley flour on rheological characteristics of dough, organoleptic, nutritional and storage characteristics of south Indian parotta. Food Science and Technology International, 21(1): 24-32.

Mariotti, M., C. Garofalo, L. Aquilanti, A. Osimani, L. Fongaro, S.Tavoletti, Anna-Sophie Hager and F.Clementi (2014). Barley flour exploitation in sourdough bread-making: A technological, nutritional and sensory evaluation. LWT - Food Science and Technology, 59(2): 973-980.

Niffenegger, E.V. (1964), chemical and physical characteristics of barley flour as related to its use in baked products. A thesis submitted to the Graduate Faculty in partial fulfillment of the requirements for the degree of Master of Science in Home Economics, Montana State College Bozeman, Montana.

Olaoye, O.A., A.A. Onilude and O.A. Idowu (2006). Quality characteristics of bread produced from composite flours of wheat, plantain and soybeans. African Journal of Biotechnology, 5(11): 1102-1106.

Preston, K.R.. O. M. Lukow, B. Morgan, (1992). Analysis of relationships between flour quality properties and protein fractions in a world wheat collection. Cereal Chem. 69, 560-567.

Patel MM, N. Chand VG. Rao (1996). Quality changes during storage of bread from wheat and black gram (Phaseolous mungo) J Food Sci Technol. 39:66-68.

Phimolsiripol, Y., A. Mukprasirt and R. Schoenlechner (2012).Quality improvement of rice-based gluten-free bread using different dietary fibre fractions of rice bran. Journal of Cereal Science 56: 389-395.

Popa, C.N., Radiana-Maria Tamba-Berehoiu, AnaMaria Hutan and S. Popescu (2014).The significance of some flour quality parameters as quality predictors of bread.Scientific Bulletin. Series F. Biotechnologies, XVIII: 135-140.

Qarooni, J.,R.A. Orth and M. Wootton (1987).A test baking technique for Arabic bread quality. Cereal Science Journal, 6: 69-80.

Różyło, R. and J. Laskowski (2011). Predicting Bread Quality (Bread Loaf Volume and Crumb Texture). Pol. J. Food Nutr. Sci., 61 (1):61-67.

Roberts, K.T., S.W. Cui, Y.H. Chang, P.K.W. Ng and T. Graham (2012). The influence of fenugreek gum and extrusion modified fen- ugreek gum on bread. Food Hydrocolloids 26: 350- 358 .

Rai, S., A. B. Kaur, K.S. Singh and Minhas (2012). Quality characteristics of bread produced from wheat, rice and maize flours. Food Sci Technology, 49(6): 786789.

Reddy, M.M., R. P. Reddy, R. Prasad and U. Munilakshmi (2013). Grain and Milling Quality of Barley and Their Suitability for Preparation of Traditional South Indian Products. IOSR Journal of Pharmacy, 4 (2): 23-27.

Sollars, W.F. and G.L. Rubenthaler (1971). Performance of wheat and other starches in reconstituted flours. Wheat and Starches in Flours, 48: 397- 410.

Schofield, J.D. (1994). Wheat proteins, Structure and functionality in milling and bread making. In Wheat, Production, Properties and Quality; Bushuk, W., Rasper, V.P., Eds.; Chapman \& Hall: London,UK, pp.: 73-106.

Sidhu, J.S., J.Al-Saqer and S. Al-Zenki (1997).Comparison of methods for the assessment of the extent of staling in bread. Food Chemistry, 58(1-2): 161-167.

Sharma, S. and U.Bajwa and H.P.S. Nagi (1999). Rheological and baking properties of cowpea and wheat flour blends. J. Sci. Food Agric., 79:657-662.

Sanchez HD, CA. Osella de la MA.Torre (2002). Optimisation of gluten-free bread prepared from cornstarch, rice flour and cassava starch. J Food Sci. 67:416-419.

Shalini D, DN. Lakshmi (2005). Development and acceptability of breads incorporated with functional ingredients. J Food Sci Technol 42(6):539-540.

Sullivan, P., J. O'Flaherty, N. Brunton, E. Arendt and E. Gallagher (2010). Fundamental rheological and textural properties of doughs and breads produced from milled pearled barley flour. Eur Food Res. Technol., 231: 441-453.

Srivastava, D., J. Rajiv, Mahadevamma, M.M. Naidu (2012).Effect of Fenugreek Seed Husk on the Rheology and Quality Characteristics of Muffins. Food and Nutrition Sciences, 2012, 3, 1473-1479

Sibanda, T., T. Ncube and N. Ngoromani (2015). Rheological Properties and Bread Making Quality of White Grain Sorghum-Wheat Flour Composites. International Journal of Food Science and Nutrition Engineering, 5(4): 176-182.

Tulse, S.B., V. Reshma, J. Rajiv and S.D. Sakhare (2014).Effect of co-milled wheat, green gram and barley on the rheological and quality characteristics of cookies. Food Sci- 
ence and Technology International, 21(7): 492-502.

Weegels, P.L. H.J. Hamer, J.D. Schofield, ( 1996). Functional properties of wheat glutenin. J. Cereal Sci.,23, 1-17.

Wieser, H. G. Zimmermann, (2000). Importance of amount and proportions of high molecular weight subunits of glutenin for wheat quality. Eur. Food Res. Technol. 210, 324-330.
Wani, I.A., D.S. Sogi, P. Sharma and B. Singh (2016). Physicochemical and pasting properties of unleavened wheat flat bread (Chapatti) as affected by addition of pulse flour. Cogent Food and Agriculture, 2: 1-9.

Yearbook of Agricultural statistics. 2016. Ministry of Agriculture and land Recliamation. Egypt. 


\section{استبدال دقيق القمح بدقيق الحبوب و البقول المحليه

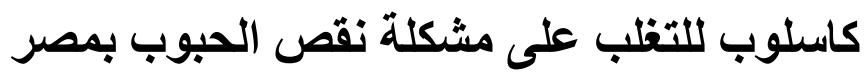 ع ـاختبارت تذوق الخبز و درجة تجلد الخبز \\ محمد عبد الستار احمد وزينب رافت عطيه و مسعد عبد السيد الجنبيهى}

الهدف الأساسي للاراسة الحالية هو تقييم إمكانية إحلال دقيق محاصيل الحبوب المحلية ممثلة بكل من الأرز

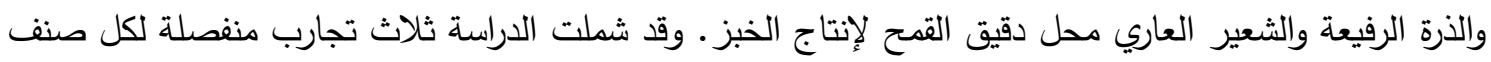
من أصناف القهح المحلي. اختلف الخبز معنوياً في نعومة القشرة (للسطح) والثكل ولون القشرة. والقابلية للطوي وجودة انفصال الطبتتين وتجانس انفصال الطبقتين ومظهر السطح بين انواع الخلطات المدروسة في حين كان التقاعل بين الاصناف والخلطات

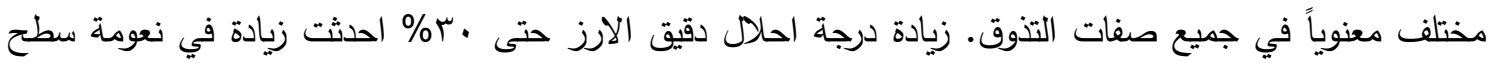

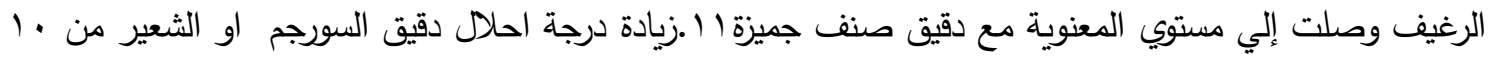

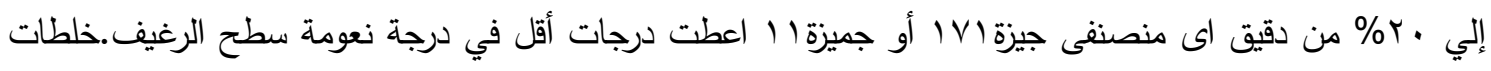

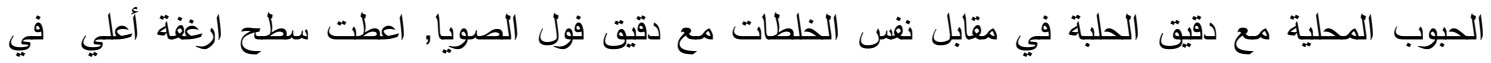

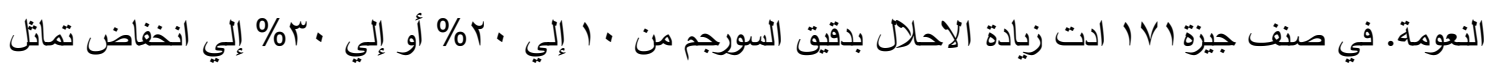

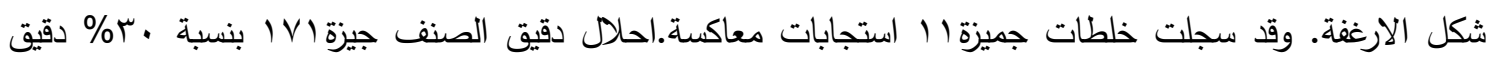

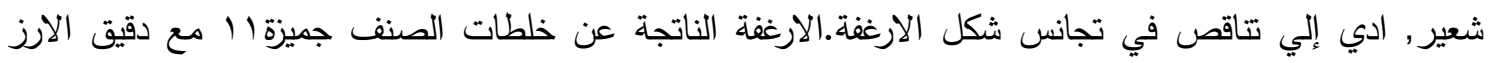

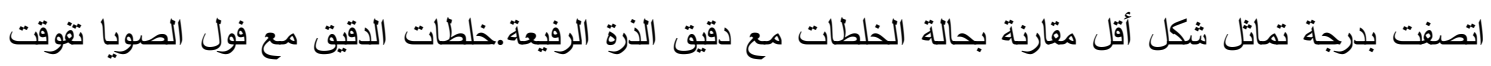

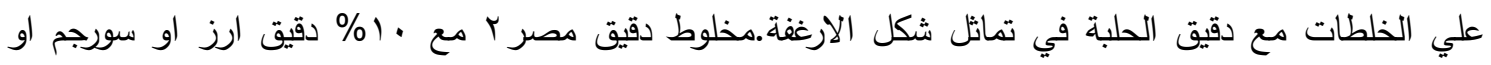

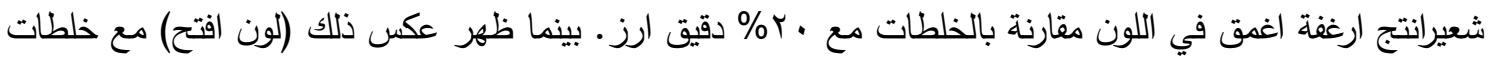

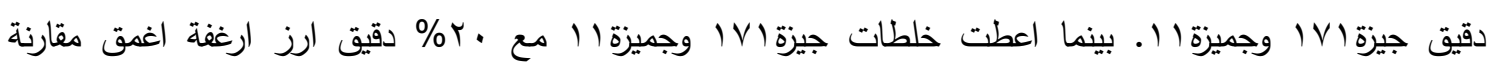

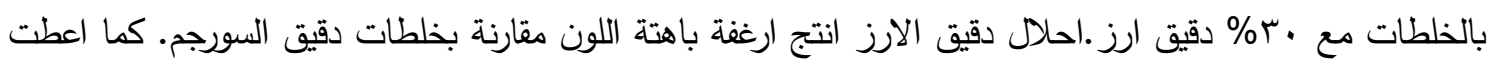

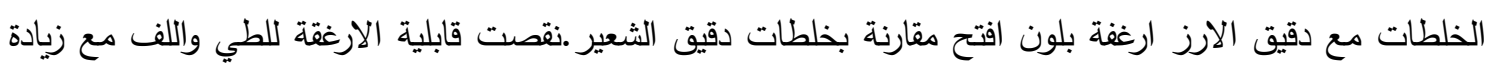

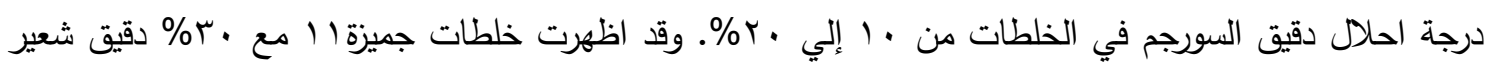

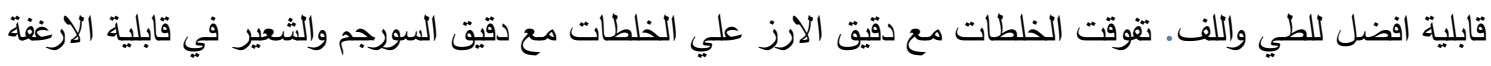

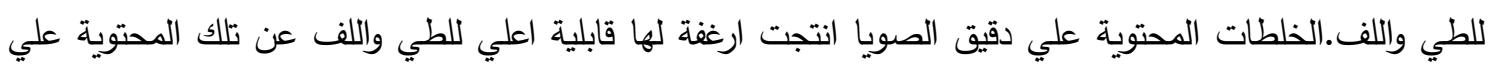

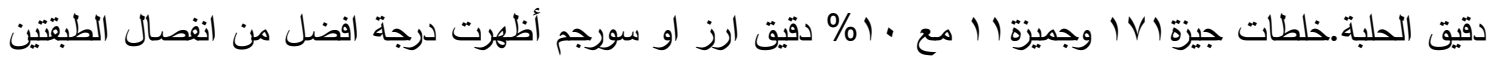

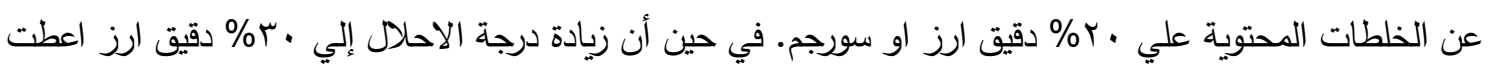

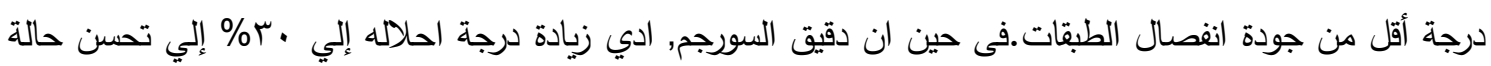

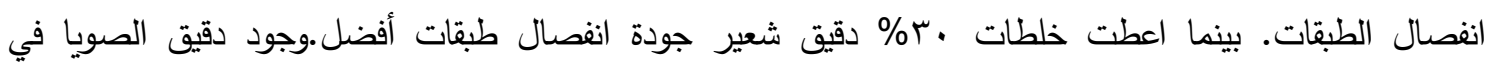

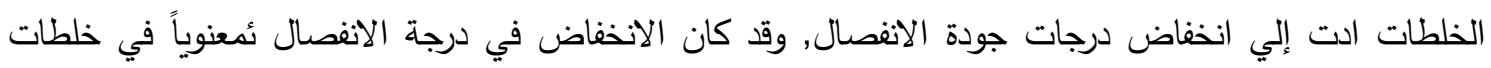

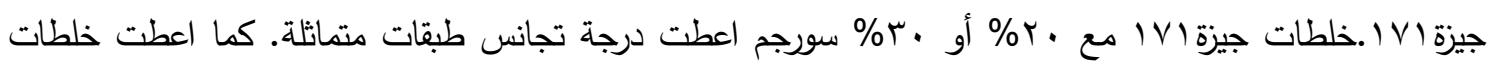

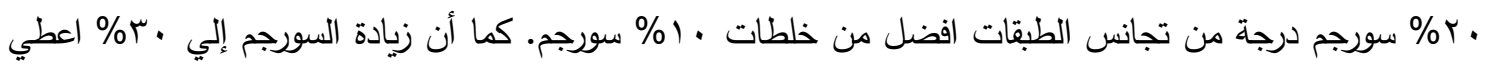




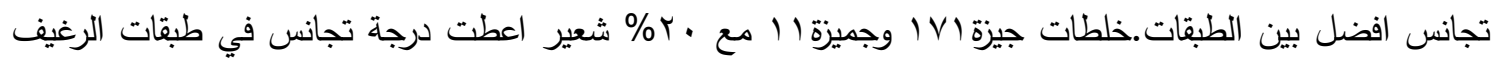

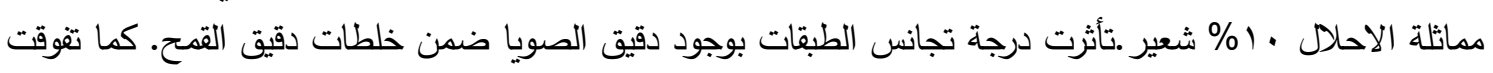

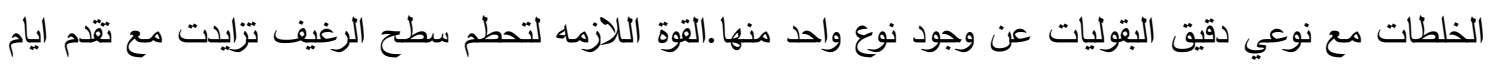

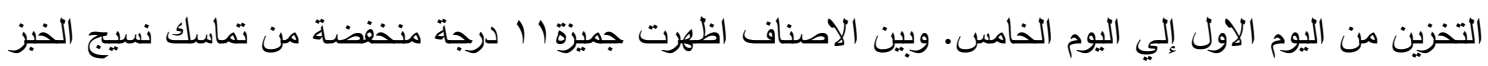
ودرجة عالية من المرونة بينما أظهر صنف مصر ب أعلي درجة صلابة.تتاقصت درجة صلابة الخبز مع احلال دقيق

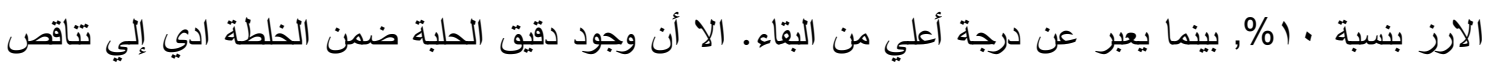

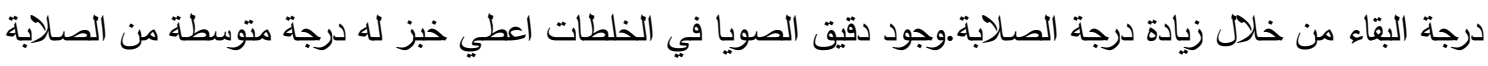

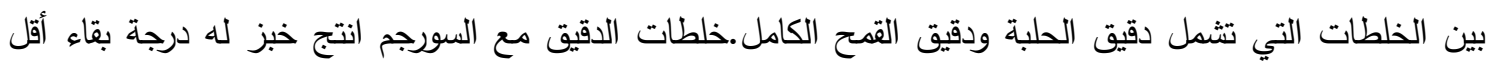
(درجة صلابة أعلي) مقارناً بالخلطات مع دقيق الارز • دور دقيق الحلبة في تقليل درجة بقاء الخبز ظهر ولكن بدرجة الخبات

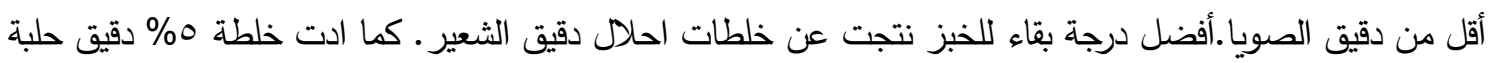

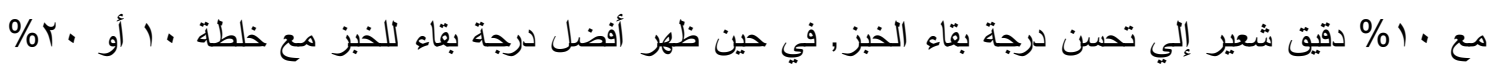

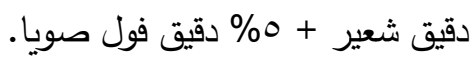


Vol. 65, No. 2, pp. 111-137, 2020

Alex. J. Agric. Sci. 